\title{
FACTORS INFLUENCING SURVIVAL OF TIGER AND LEOPARD IN THE HIGH-ALTITUDE ECOSYSTEM OF THE NILGIRIS, INDIA
}

\author{
Govindarajan Mohan a, Jayakumar Yogesh ${ }^{a, b}$, George Nittu ${ }^{a}$, Thekke Thumbath Shameera, Sulekha Jameela \\ Backer $^{a}$, Subramani Nandhini ${ }^{a, b}$, Balasundaram Ramakrishnan ${ }^{\text {a,b }}$, Manikkiri Jyothic, Raveendranathanpillai \\ Sanil $^{\mathbf{a}^{*}}$
}

\author{
${ }^{a}$ Molecular Biodiversity Lab., Department of Zoology and Wildlife Biology, Government Arts College, \\ Udhagamandalam-643002, The Nilgiris, Tamil Nadu, India \\ ${ }^{b}$ Mudumalai Tiger Conservation Foundation, Tamilnadu Trust, Udhagamandalam-643002, The Nilgiris, India \\ 'Department of Zoology, Providence College for Women, Spring Field P.O., Coonoor-643104, The Nilgiris, Tamil Nadu, India \\ *Corresponding author. Email: sanilravi@live.in
}

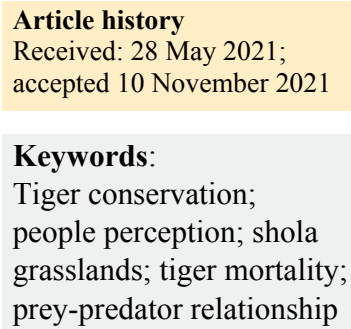

Keywords:

Tiger conservation; people perception; shola grasslands; tiger mortality; prey-predator relationship

\begin{abstract}
Tiger conservation is a global initiative, and data on distribution, prey dynamics, competition, and range extension are critical factors in sustaining its fragile populations. We concentrated on evaluating the data pertaining to these variables in order to designate the high-altitude Nilgiri forest division as a tiger conservation unit. We gathered secondary data on animal density, mortality, and conflicts. We also conducted a people perception survey, a systematic grid-based prey species survey, and a tiger and leopard scat survey to assess the prey-predator relationship and understand human attitudes toward carnivore conservation. According to the findings, the Nilgiri forest division has a healthy prey base with positive or random prey-predator associations and a significant correlation between mammalian assemblages. Because the niche overlap between the tiger and the leopard is high, the latter broadens its niche and relies on wild prey in the shola fringes and tea estates. The tiger avoids human-dominated areas and prefers to stay in the shola, rarely venturing into tea estates. In contrast to previous considerations, we believe the Nilgiri forest division is an ideal tiger habitat. We specify that instead of being considered a connective corridor, the Nilgiri forest division may be merged with Mukkurthi National Park to form a high-altitude tiger reserve.
\end{abstract}

\section{INTRODUCTION}

The implementation of Project Tiger in the year 1973 made substantial progress in the Indian tiger conservation (Nayak et al. 2020). The extended efforts of the National Tiger Conservation Authority (NTCA) facilitated proper documentation of tiger abundance and occupancy in the different landscapes across India (Jhala et al. 2020). The implementation of Project Tiger also includes conservation with people participation and sustainably protecting their livelihood. New tiger reserves are coming into existence to broaden the endangered felid habitat, connectivity, and gene flow (Jhala et al. 2008; Hines et al. 2010; Yumnam et al. 2014; Singh et al. 2017; Kolipakam et al. 2019; Jhala et al. 2020). India's principal tiger conservation blocks are six major landscapes, including the high-altitude regions (Jhala et al. 2020), with major conservation units (tiger reserves) in lower altitudes. The tigers in the high-altitude pockets of the western Arunachal Pradesh were thought as extinct (Mishra et al. 2006), later Adhikarimayum and Gopi (2018) identified tiger presence in this region. Monitoring by the Global Tiger Forum (2019) identified the presence of tigers in high-altitude Himalayan regions of several Indian states (like Bengal, Sikkim, and Arunachal), as well as Nepal and Bhutan. The highaltitude tiger habitats have the potential to mitigate the issues related to climate change (Aggarwal 2019). In the approaching years of global warming, such habitats will become crucial conservation units and need to be protected with topmost priority. The high-altitude ecosystems of Nilgiris are less focused concerning predation and inter-species interactions of the tiger and its sympatric counterparts.

The problem of human-carnivore conflicts is a universal issue, where the people's attitude towards predators is vitally essential (Bhattarai and Fischer 2014). The conflicts with bigger carnivores can be fatal, ending in the retaliatory killing of predators (Wang and Macdonald 2006; Gurung et al. 2008; Inskip and Zimmermann 2009; Singh et al. 2015a, b). According to research from various landscapes, the rate of tiger and leopard mortalities varies, which may lead to a decline in the carnivore population in the landscape (Athreya et al. 2011; Singh et al. 2015a, b; Gubbi et al. 2021). Conflicts are primarily caused by predators' reliance on livestock due to a lack of wild prey, as well as inter-and intra-species competition (Bhattarai and Fischer 2014). The people's perception plays a significant role before drawing the conservative measure, otherwise it lacks local support (Graham et al. 
2005). The people perception studies from the adjoining Mudumalai Tiger Reserve (Ramesh et al. 2019) indicate that attitudes differ among various local groups. The illiterate and those who depend on the firewood and forest products are hostile towards carnivore conservation efforts. Crop raiding intensity, the presence of wild herbivores in the village vicinity, and cattle picking are all indirect indicators of prey availability in the adjacent reserves. The negative human interactions directly or indirectly affect the trophic structure and transform the ecological communities (Woodroffe and Ginsberg 1998; Crooks 2002; Karanth et al. 2004).

The abundance of prey in an ecosystem determines the density of big cats (Carbone and Gittleman 2002; Treves and Karanth 2003; Karanth et al. 2004; Selvan et al. 2013). Prey availability, habitat suitability, and intra-guild competition all influence the presence of large predators (Gompper et al. 2016; Kafley et al. 2019). A good prey base, primarily ungulates, maintains a viable tiger population, whereas leopards consume a wide range of prey, including small and arboreal prey (Karanth and Sunquist 1995; Ramakrishnan et al. 1999; Karanth and Sunquist 2000; Harihar et al. 2007; Wegge et al. 2009; Karanth et al. 2011; Selvan et al. 2013; Thapa and Kelly 2017). Due to its larger body size than the leopard, the tiger includes prey of a higher weight class in its diet, allowing it to maintain a stable large prey population (Seidensticker 1976; Karanth et al. 2004). Tigers prefer relatively large and uninterrupted ranges with plenty of prey and avoid human settlements (Karanth et al. 2004; Wang and Macdonald 2009; Odden et al. 2010; Bhattarai and Kindlmann 2018). They prefer open grasslands, logged areas, and bordered areas as their primary habitats, whereas leopards are highly malleable and rely on human-modified landscapes such as croplands, tea estates, and agricultural plantations for movement, and the tiger avoidance varies depending on prey density (Johnsingh 1983; Bailey 1993; Linkie et al. 2003; Odden et al. 2010; Athreya et al. 2013; Bhattacharjee and Parthasarathy 2013; Navya et al. 2014; Odden et al. 2014; Sidhu et al. 2015; Kshettry et al. 2017). Studies demonstrated that when the tiger dominates in an ecosystem, the major co-predator (leopard) occupies the fringe and attempts to predate on livestock (Singh et al. 2013; Athreya et al. 2015; Gubbi et al. 2020; Puri et al. 2020). The co-existence of tiger and leopard is also influenced by landscape variability and human intervention (Gompper and Vanak 2008; Ripple et al. 2014; Karanth et al. 2017; Kshettry et al. 2017; Kafley et al. 2019; Thapa et al. 2021).

Sympatric predators can coexist, with limited competition, if the prey base is sufficient and resource portioning is effective (Selvan et al. 2013; Thapa and Kelly 2017). The people's perception of larger felid mortality, prey richness, and prey-predator relationship is not ad- dressed in the upper Nilgiris, because the region is not considered a primary habitat for tigers and leopards. Population growth and activities such as urbanisation, agriculture, and tourism are on the rise in this landscape, with much of the shola region remaining fragmented and grasslands being replaced by tea plantations. The analysis of the trophic structure, conflict, mortality, and resource partitioning are of utmost importance to review the quality and suitability of the habitat in the NFD. The human-animal conflict is vital in understanding the prey base and prospects of sustainable conservation. The initial objective of our study was to assess the people's perception of wild animal presence and monitor the conflicts in the fragmented fringe areas and tea gardens. Secondly, we surveyed the prey encounter proportion and co-occurrence of tiger, leopard, and prey species in the forested and fringe areas. The final objective was to assess the prey utilisation by the co-predators in terms of dietary partitioning, niche breadth, and niche overlap.

\section{MATERIALS AND METHODS}

\section{Study area}

The Nilgiri forest division (NFD) is a new forest administrative unit formed by modifying the former Nilgiri South Forest Division (Figure 1). Tiger conservation units like Mudumalai, Sathyamangalam, Bandipur, and the Wayanad connects NFD from all sides (Jhala et al. 2020). The Nilgiri Hills are old mountain ranges and gain immense significance as they represent the point where the Eastern Ghats Mountain chain merges with the Western Ghats Mountain chain, reaching an altitude of $\sim 2500 \mathrm{~m}$ asl. The Nilgiris is noted for its high level of endemism and is part of the Nilgiri Biosphere Reserve, a UNESCO recognized world heritage site. The Nilgiri North Division is located between $11^{\circ} 10^{\prime}$ and $11^{\circ} 30^{\prime} \mathrm{N}$ latitude and $76^{\circ} 25^{\prime}$ and $77^{\circ}$ $00^{\prime} \mathrm{E}$ longitude, includes the tehsils of Udhagamandalam (Ooty), Coonoor, Kotagiri, and Kunda. The NFD has eleven forest ranges (Paykara, Naduvattom, Parsons Valley, Korakundha, Udhagamandalam North and South, Kundha, Governor shola, Coonoor, Kattabettu, Kottagiri, and the Eastern Slopes of the Nilgiris) and 62 forest beats. The Nilgiri Forest Division shares boundary with the Mudumalai Tiger Reserve, Sathyamangalam Tiger Reserve, Mukkurthi National Park, Gudalur, Coimbatore Forest divisions (Tamil Nadu state), and the Silent Valley National Park (Kerala State).

The NFD has pine forests, Eucalyptus plantations, wattles, and fragmented shola regions interspersed with tea estates and agricultural lands. The total area of the forest division is $1,251.09 \mathrm{~km}^{2}$, which includes $604.11 \mathrm{~km}^{2}$ dense or medium forests, $359.59 \mathrm{~km}^{2}$ open forests, $24.98 \mathrm{~km}^{2}$ water bodies, and the remaining 262.42 $\mathrm{km}^{2}$ non-forested region as per Bhuvan database, ISRO, 


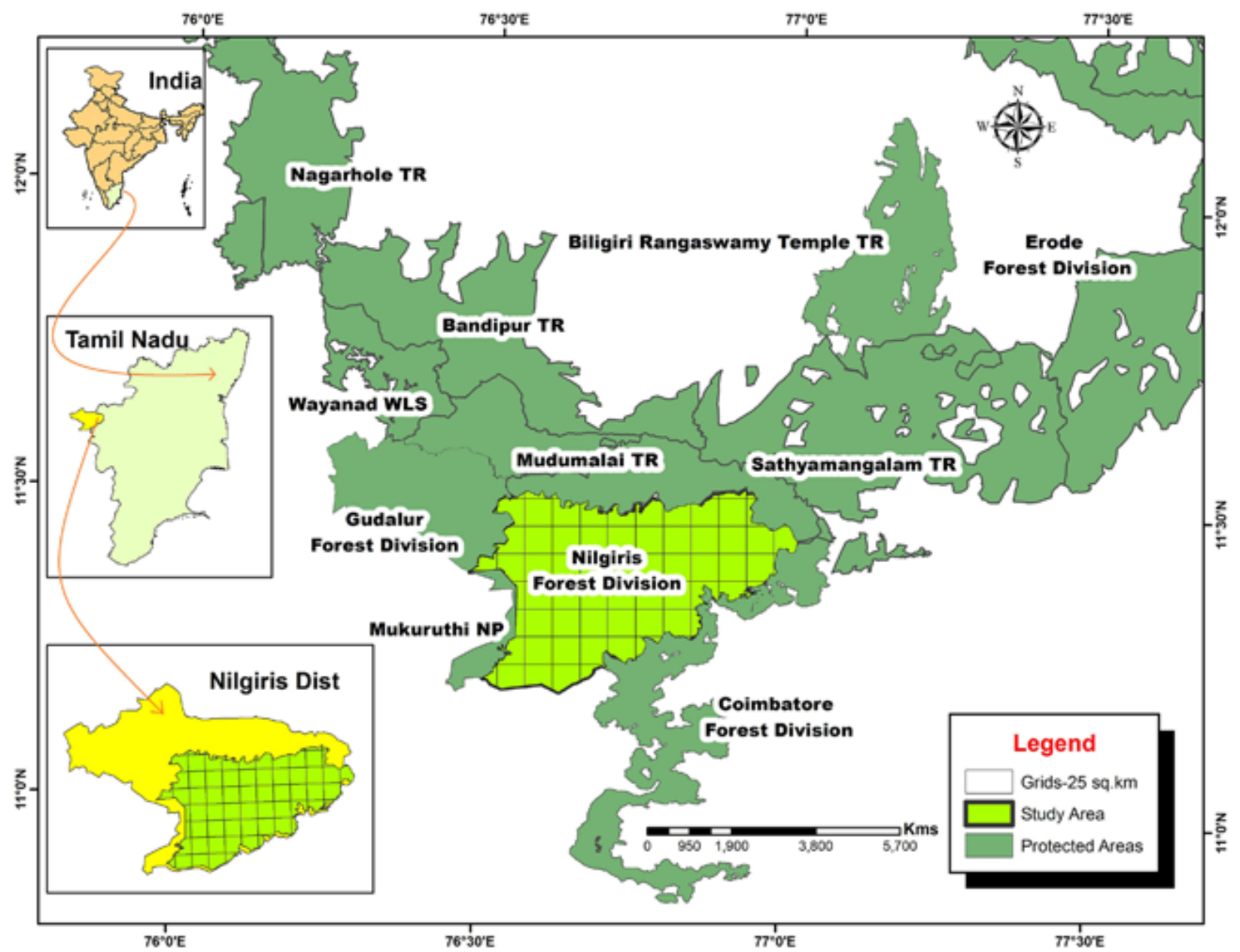

Figure 1. Study area map. The map shows the connectivity of the study area with other reserves. The sampled regions are presented as grids of $5 \times 5 \mathrm{~km}$ which include both reserve and non-reserve areas.

India (http://bhuvan.nrsc.gov.in/). The existing natural vegetation is classified as southern montane wet temperate forests, Nilgiri sub-tropical hill forests, western sub-tropical hill forests, and southern dry mixed deciduous forests (Champion and Seth 1968). The temperature significantly rises to as high as $27^{\circ} \mathrm{C}$ in April-May and drops to as low as $-4^{\circ} \mathrm{C}$ in winter during DecemberJanuary. The plateau receives both the southwest and northeast monsoons, where the western rim (the Kundha region) gets the highest rainfall $(\sim 7,500 \mathrm{~mm})$ during the southwest monsoon (June-August). The northeast monsoon is foremost in the western slopes (OctoberNovember), and the region is mainly human habituated. The Doddabetta range acts as a barrier to the free movement of the monsoon winds, dividing the plateau into two distinct climate zones.

\section{Accession of secondary data}

The general animal census data (2006-2016) of the Tamil Nadu Forest Department is accessed and used for our primary analysis. The ten years mortality and conflict data of tiger and leopard in the NFD was also obtained from the forest department. We also used the all-India tiger census data 2018 (Jhala et al. 2020) to assess the number of tigers, tiger density, and sex ratio in this region.

\section{Questionnaire survey}

We conducted a random questionnaire survey among the villagers/residents of houses /agriculturalists from the villages adjoined to the study location as a primary response. As the respondents are villagers from an agricultural background, we prepared the questionnaire in Tamil (the language of Tamil Nadu state) and orally explained it by the volunteers in the local language (Badaga), if needed. The questionnaire consists of 15 questions targeting the socio-economic status of respondents, details of wild herbivores, carnivores, and conflicts for the past ten years in their locality. We used the term livestock for domesticated ruminants and poultry for the domesticated fowls. The questions framed were short, direct, and simple to avoid response bias. We assessed the homogeneity of the responses by the chi-square test $\left(\chi^{2}\right)$ and ignored the skewed responses. 
The survey helped us understand people's perception of tigers and leopards in their region, conflicts, cropraiding, livestock, and cattle lifting.

\section{Grid survey}

We divided the entire NFD into a grid of 70 cells $(5 \times$ $5 \mathrm{~km}$ ) of $25 \mathrm{~km}^{2}$ using QGIS software (QGIS Development Team 2009) for systematic sampling. These grids are heterogeneous as they include the reserve areas (shola-grasslands), plantations, exotics, watershed regions, and human habituations. We surveyed the track paths and possible tracks of three segments comprising a $15 \mathrm{~km}$ walk in every grid cell. We sampled between 9.00 am and 3.00 pm from November to June in 2017-2018, and the effort taken was estimated as $3 \times 70=210$ sampling attempts in $5 \mathrm{~km}$ sampling segments for 70 grid cells ( $\sim 15-20 \mathrm{~km}$ walk per day, which may cross multiple grids). We walked through the forest roads, track paths, and animal trails to record the direct and indirect signs. As a fragmented habitat, the track paths include shola vegetation, grasslands, Eucalyptus, Pinus, and wattle regions, tea gardens, other bushy forests, riparian regions, and agricultural areas. We use the term "shola region" to imply the shola forests, grasslands, forested areas, or forest plantations existing in the reserve forest areas and not actual shola vegetation alone. The scats, dungs, pellets, and signs were field identified and photographed for further confirmation. We collected the tiger and leopard scats in zip lock covers, with the details of GPS location.

\section{Grid referencing and encounter ratio}

According to the grids, the occurrence prints of various prey and predator species were plotted over the grid map in ArcGIS and tabulated further. The encounter proportion was estimated as the cumulative value of indirect signs and direct observations of a particular species per single effort (distance travelled in the grid through survey track). The prey species were classified as large prey $(>200 \mathrm{~kg})$, medium prey $(>10 \mathrm{~kg})$, and arboreal prey, and the cumulative encounter proportion, as well as the tiger and leopard, were mapped in the grid maps.

\section{Scat identification}

The tiger scat was differentiated from the leopard scats based on shape, size or diameter, endpoint, and presence of secondary evidence, i.e. pugmark (Norton et al. 1986; Rabinowitz 1989). The leopard and tiger scats are usually associated with tracks and signs, but some of the scat samples we collected were not associated with trails and signs. Tiger scats are less coiled with a more considerable distance between two successive constrictions (Johnsingh 1983). The herbivore dung and pellets were identified based on the shape and size and compared to the dried/preserved fecal specimens of herbivores maintained in our lab. Predator scat DNA was isolated using the QIAamp DNA Stool Mini Kit (QIAGEN, Cat No. / ID: 51504). We did the tiger and leopard identification using the AS-Nested method developed in our lab. (for detailed methodology, see Nittu et al. 2021).

\section{Prey species identification}

The complete hair samples or prey species were recovered in triplicate from the scat samples and washed in warm water. The hair samples were further fixed in formaldehyde $(3 \% \mathrm{v} / \mathrm{v})$, dehydrated in alcohol, cleared in xylene, and mounted using dibutylphthalate polystyrene xylene (DPX) in glass slides for trichological identification. The hair samples were observed for the proximal, distal, and middle regions to follow the cellular arrangement pattern. The length and breadth of the hair were also measured using micrometry, and we identified the prey species following the standard keys (Koppikar and Sabnis 1976; Easa 1995). We also compared the hair samples with the reference hair samples in the trichology collection of Molecular Biodiversity Lab., Ooty.

\section{Frequency, rare resources, niche breadth, and overlap} The prey species frequency was calculated based on the scats collected, as the number of events of that prey species was divided by the total number of scats analyzed (Ackerman et al. 1984). Evenness measure (J)' of the Shannon-Wiener function (Colwell and Futuyma 1971; Hill 1973) scaled between 0 and 1 (scaled H') was used to understand the rare resources used by the predator. We estimated the niche breadth following the Levins (1968) equation by measuring distribution uniformity among the resource states. The niche breadth is standardized on a 0 to 1.0 scale by dividing the total number of resource states after correcting a finite number of resources (Hurlbert 1978). We followed Pianka's measure (Pianka 1986) to estimate the niche overlap between the tiger and the leopard.

\section{Species co-occurrence}

We used the 'co-occur' package (Griffith et al. 2016) in Rstudio (Rstudio Team 2020) to assess the spatial cooccurrence of the tiger and leopard with various prey species. This package helps to analyse the co-occurrence of the co-predators and prey using a probabilistic model described by Veech (2013). The package allows us to calculate the co-occurrence of two species at a lower $\left(P_{l t}\right)$ or greater frequency $\left(P_{g t}\right)$, which interprets it as a positive or negative co-occurrence (Shankar et al. 2020). We used the "ggpair" function of the GGally package in the RStudio to visualize the encounter scatter plot matrix. 


\section{RESULTS}

\section{Secondary data analysis}

The available general census data (2006-2016) of the forest department (of the Nilgiri South Forest Division) indicated the presence of the sambar deer, Indian gaur, barking deer, wild pig, Nilgiri langur, bonnet macaque, giant squirrel, and Nilgiri tahr. The carnivores reported in the census were the tiger, leopard, hyena, wild dog, bear, jackal, and lesser cats. The report says there are not more than 2 or 3 tiger sightings during the entire period, and the most abundant number of carnivores reported was the wild dog, followed by the jackal and leopard. The ten-year census summary of the forest department is presented as an error bar and given as supplementary data (Supplementary Figure S1). The tiger census data of 2018 based on the camera trapping of NTCA (Jhala et al. 2020) shows 34 individual tigers in the Nilgiris forest division and four tigers in Mukurthi (a high-altitude National Park adjoined to the NFD). The tiger census of 2018 documented the tiger density in Nilgiris (NFD) as $3.04 \pm 0.52 / \mathrm{km}^{2}$ and the sex ratio as $\sim 1: 2$.

According to the forest department's data (Supplementary Figure S2), five tigers (rate $=0.5 /$ year) and eleven leopards (rate $=1.1$ year) have died in the last ten years. Among the dead tigers, except one, all the others occurred in the reserve forest (shola regions). One death was reported due to poisoning as retaliation against livestock lifting. The case reports say that poisonous pesticides like fenvalerate were poured over the remaining carcass in the shola fringe. In contrast, all leopard deaths occurred outside the shola regions (one is a black panther) near human habituations or tea plantations. Two leopards died by accidentally getting entangled in the snare.

\section{People perception analysis}

We received 360 responses to the questionnaire from the fringe villages in the NFD. The respondents chiefly (74\%) included males aged 30-60, finding their livelihood as tea leaf pickers (36\%), firewood collectors $(19 \%)$, and agriculturalists $(45 \%)$. They primarily responded that the herbivores are a nuisance and not carnivores $(84 \%)$. They complained about the carnivores as the reason for lifting livestock and poultry, but as an occasional one. Among the respondents, $47 \%$ opined that livestock lifting is rare (1 or 2 liftings/year), while $85 \%$ responded yes to the frequent poultry picking. The gaur (Bos gaurus) is a common occurrence in the tea estates ( $95 \%$ of respondents) and sometimes an annoyance to agriculturalists (43\%). They identified the animals like sambar deer (Rusa unicolor) (47\%), barking deer (Muntiacus muntjac) (82\%), wild pig (Sus scorfa) (100\%), bonnet macaque (Maccaca radiata) (73\%), black langur
(Trachipithicus johni) (21\%), porcupine (Hystrix sp.) $(89 \%)$ as very common crop raiders. The carnivores like jungle cat (Felis chaus) (63\%), mongoose (Herpestes sp.) (91\%), bear (Ursus sp.) (54\%), and leopard $(48 \%)$ are frequently sighted in the tea plantations and fringe villages. Villagers rarely sighted a tiger (7\%) and opined that it would remain only in the shola and never sighted in the fringe areas and tea plantations. The survey indicates ( $\sim 85 \%$ of respondents) that people do not like the leopard or the tiger in their locality. Regarding the question to human-animal conflict, $82 \%$ opined major conflict is with crop raiding herbivores and 5\% opined of human-carnivore conflicts.

\section{Co-occurrence and distribution}

We identified the tiger presence from $45(61 \%)$ grid cells and the leopard from 56 (68\%). In 44 (59\%) grids, we observed the coexistence of the tiger and leopard. The grids surveyed include tea plantations, shola regions, social forestry sites, hydro-electrical sites, revenue lands and village suburbs. The areas surveyed towards the southern and western sides have pristine shola regions with grassland and are protected from human disturbances. Much of the forested areas adjoined to the shola have exotic weeds like Lantana, Parthenium, and Eupatorium. The results of positive, random, and negative interactions analyzed using the "co-occur" $R$ package are given in Figure 2. Please refer to supplementary material for the grid-wise consolidated results of the prey, predator, and co-occurrence (Supplementary Table S3). Most of the observed associations are positive, indicating a harmonious co-existence of both the predators and the prey. The positive associations indicate prey abundance, lesser competition, and resource partitioning in the NFD. None of the species pairs (preypredator) showed negative interaction. At the same time, we observed random associations between the gaur and livestock (sheep and goat), feral buffalo, livestock, and mouse deer with elephant, and notably mouse deer-tiger. The categorized geo-referenced encounter rates (Figure 3 ) showed that the tiger distribution is located explicitly in forested regions. At the same time, the leopard has a comparatively wide range of distribution, including the dominant human habituations. The leopard seems to coexist with the tiger in the shola regions, where large prey and arboreal prey are abundant. The distribution of the leopards in the other areas follows the distribution pattern of the medium-small range prey, predominantly in the plantations (majorly tea gardens) and grasslands.

The correlation scatter plots matrix of encounter proportion of the tiger and the leopard with various prey and between prey species (Figure 4) shows tiger-sambar and gaur-sambar significantly correlate $(r \geq+0.75, p \leq 0.05)$. 


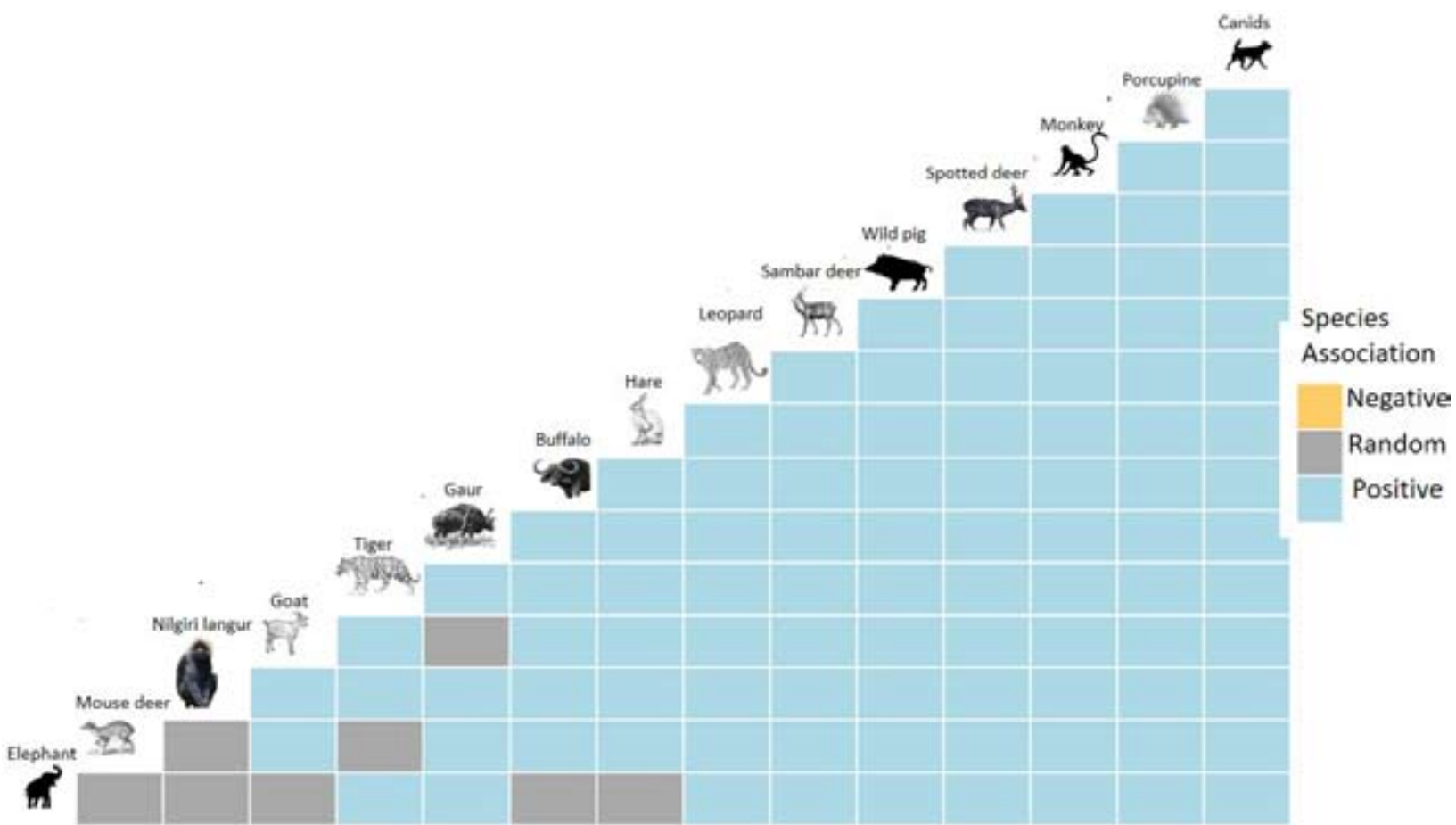

Figure 2. Species co-occurrence in NFD. The grey indicates random associations, and the blue indicates positive association, no negative associations were observed.


Figure 3. Grid-wise density of tiger, leopard, various categories of prey. The topography of grids laid in the reserve is shown in the right side bottom. NF: Non Forest, MDF: Moderate Dense Forest DF: Dense Forest..

Most prey species exhibited a moderate correlation $(r=0.50-0.75)$ with the tiger and the leopard. The average correlation shown by the tiger is with the leopard $(+0.658)$, wild pig $(+0.684)$, gaur $(+0.606)$, porcupine $(+0.677)$, Nilgiri langur $(+0.627)$, black napped hare $(+0.627)$, barking deer $(+0.618)$, and bonnet macaque $(+0.556)$ in sequential order. The leopard also shows a moderate correlation with the barking deer $(+0.699)$, wild pig $(+0.677)$, gaur $(+0.648)$, bonnet macaque $(+0.609)$, black napped hare $(+0.607)$, and porcupine $(+0.614)$. The other considerable high degree of significant correlation is between the wild pig-barking deer $(+0.898)$, porcupine-black napped hare $(+0.848)$, and sambar-gaur $(+0.77)$ pairs. 


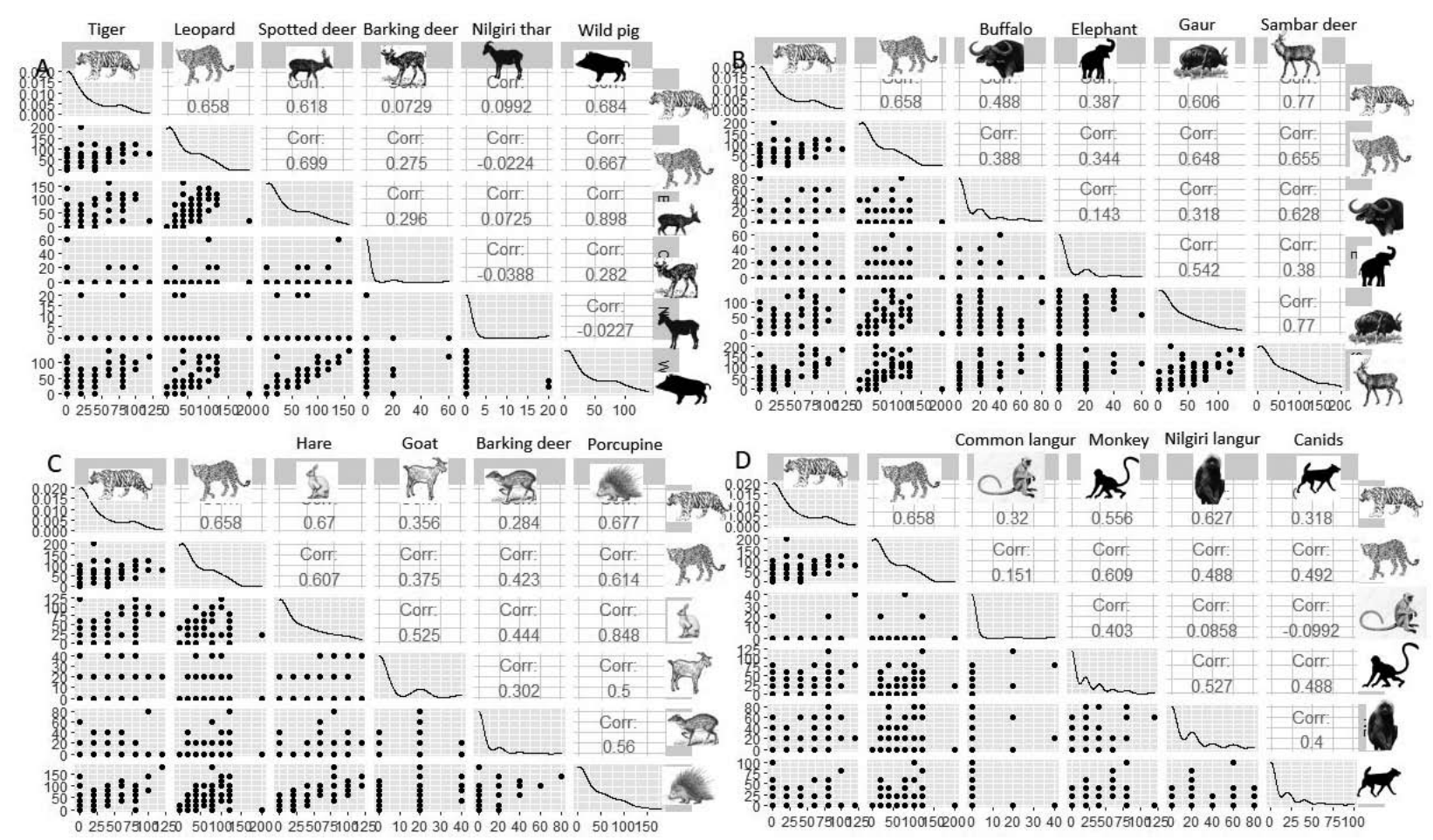

Figure 4. Correlation of encounter proportion of tiger and leopard with various mammalian species. The scatter plot is shown in the lower half, the Pearson coefficient (r) is shown in the upper half, and in the middle is the slope line.

Table 1. Prey species, prey proportion and prey biomass of tiger $(\mathrm{N}=67)$ and leopard $(\mathrm{N}=95)$. Mann Whitney $\mathrm{U}(\mathrm{U}=65.5$, $\mathrm{Z}$-score $=-1.92873)$ indicates there is a significant difference between the prey of tiger and leopard $(p \leq 005)$.

\begin{tabular}{|l|c|c|c|c|c|c|}
\hline \multirow{2}{*}{ Prey species } & \multicolumn{2}{|c|}{ No of prey specimens in scat } & \multicolumn{2}{c|}{ Prey proportion (\%) } & \multicolumn{2}{c|}{ Prey biomass $(\mathrm{kg})$} \\
\cline { 2 - 7 } & Tiger & Leopard & Tiger & Leopard & Tiger & Leopard \\
\hline Rusa unicolor & 41 & 12 & 61.19 & 12.63 & 368.18 & 107.76 \\
\hline Muntiacus mutjac & 06 & 30 & 08.96 & 31.58 & 014.82 & 074.10 \\
\hline Lepus nigricollis & 02 & 19 & 02.99 & 20.00 & 004.31 & 040.95 \\
\hline Ratufa indica & 00 & 04 & 00.00 & 04.21 & 000.00 & 008.20 \\
\hline Petaurista philippensis & 00 & 01 & 00.00 & 01.05 & 000.00 & 002.05 \\
\hline Trachypithecus johnii & 00 & 01 & 00.00 & 01.05 & 000.00 & 002.26 \\
\hline Macaca radiata & 00 & 03 & 00.00 & 03.16 & 000.00 & 006.57 \\
\hline Loris lydekkerianus & 00 & 02 & 00.00 & 02.11 & 000.00 & 003.99 \\
\hline Aves & 00 & 02 & 00.00 & 02.11 & 000.00 & 004.00 \\
\hline Bos gaurus & 06 & 02 & 08.96 & 02.11 & 158.88 & 052.96 \\
\hline Axis axis & 01 & 04 & 01.49 & 04.21 & 003.03 & 012.12 \\
\hline Moschiola indica & 02 & 04 & 02.99 & 04.21 & 004.14 & 008.27 \\
\hline Sus scrofa & 08 & 09 & 11.94 & 09.47 & 029.00 & 032.63 \\
\hline Bubalus bubalis & 01 & 00 & 01.49 & 00.00 & 013.15 & 000.00 \\
\hline Ovis aries & 00 & 02 & 00.00 & 02.11 & 000.00 & 005.71 \\
\hline Total & $\mathbf{6 7}$ & $\mathbf{9 5}$ & $\mathbf{1 0 0}$ & $\mathbf{1 0 0}$ & $\mathbf{5 9 5 . 5 0}$ & $\mathbf{3 6 1 . 5 5}$ \\
\hline
\end{tabular}

\section{Scat identification}

We collected 182 scats from the reserve during the survey. The molecular analysis showed 67 scats belong to the tiger and 95 belong to the leopard. The remaining scats remain unidentified, hence ignored.

\section{Prey analysis}

Table 1 shows the details of prey and its proportion in tiger and leopard scats. The prey species observed in the leopard scats are the sambar deer (Rusa unicolor), barking deer (Muntiacus mutjac), black napped hare (Lepus nigricollis), giant squirrel (Ratufa indica), flying squirrel (Petaurista philippensis), Nilgiri langur (Trachypithecus johnii), bonnet macaque (Macaca radiata), slender loris (Loris lydekkerianus), birds (Aves), gaur (Bos gaurus), spotted deer (Axis axis), mouse deer (Moschiola indica), wild pig (Sus scrofa), and domestic goat (Ovis aries). The prey species obtained from the tiger 
scats are the sambar deer, buffalo (Bubalus bubalis), barking deer, black napped hare, gaur, spotted deer, mouse, deer, and wild pig. Our comparison of tiger and leopard prey proportions with non-parametric Mann Whitney $\mathrm{U}$ indicated that the prey vary significantly $(\mathrm{U}=65.5, \mathrm{z}$-score $=-1.92873, p \leq 0.05)$. Sambar seems to be the chief prey of the tiger and the leopard, while barking deer, arboreal prey, and hare observed more in the leopard diet. The mouse deer and livestock are solely restricted to the leopard scat, while the wild boar was observed to be present in both tiger and leopard scats. The buffalo seems to be present only in the tiger scat, while the gaur dominates in the tiger scat.

\section{Niche breadth, diversity and overlap}

We represented the niche breadth, prey diversity, and prey overlap in a Venn diagram (Figure 5), which confirms that the leopard has a broader niche (0.29) than the tiger (0.19). The Shannon Index of Diversity (Scaled H) shows that the leopard's prey diversity was 0.65 (included more prey states), while the tiger's was 0.5 . This is an indirect example of resource partitioning because one includes a greater diversity of prey than the counterpart. A significant niche overlap (0.84) indicates that the two co-predators eat similar species considerably.

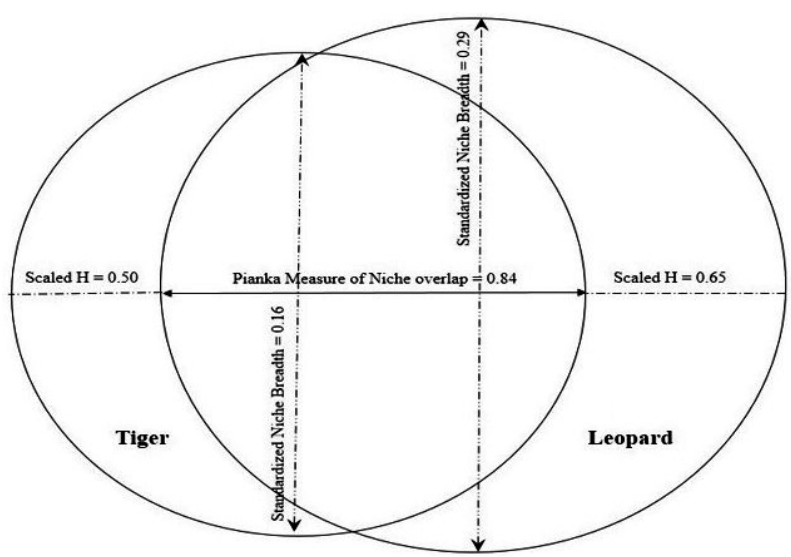

Figure 5. Venn diagram demonstrating niche breadth, niche overlap, and prey diversity of tiger and leopard. Leopard has more niche breadth and includes more prey states in the diet than tiger.

\section{DISCUSSION}

The NFD embraces an exceptionally high-altitude ecosystem having pristine montane shola-grasslands with remarkably high endemism and diversity. Due to massive human exploitation for plantation and developmental activities in the post-Indian independence, the continuity of shola-grasslands shrank and became patchy. The conservation pace increased in India by the end of the last and start of this century, with the declaration of sanctuaries, national parks, and tiger reserves. The report of 34 individual tigers in the 2018 all-India tiger census report (Jhala et al. 2020) raised curiosity, as the NFD is not considered a prime tiger habitat. As given in the present study, the previous direct census observed only one or two tigers from the reserve. According to Johnsingh et al. (2010), most large mammals in this region occupy the previously identified protected areas. They also did not prioritize the NFD as a tiger conservation unit but as a high-altitude corridor or migratory path connecting the adjoined reserves. We argue the camera-trapped tigers in the Nilgiris cannot be a spillover population (see the sex ratio of 1:2) or migratory tigers, but belong to a resident population. Even tigers with leucism were reported from the high altitude of the Nilgiris (Jhala et al. 2021). Leucism in felids is an expression of the recessive allele (Sanil et al. 2014) and happens in a population due to inbreeding or a stabilized trait as in the Sundarbans or Simlipal (Jhala et al. 2021; Sagar et al. 2021). The presence of such trait ascertains the fact that a resident population of tigers exists in the NFD and adjoining areas.

The people perception survey clearly indicates that they have never or rarely sighted a tiger in human habituations or agricultural areas, but are aware that the tiger is inside the shola forest. The case of the leopard is different, where villagers frequently sight the leopard in tea estate and shola fringes. The villagers are mostly bothered about the herbivores than the carnivores, as they are the major crop destroyers. According to them, herbivores like the gaur, wild pig, sambar deer, barking deer, and porcupine are very common in the tea estates. Sheep and buffalo rearing are common practices, and the reports of the livestock picking is comparatively less than from other landscapes (Singh et al. 2013; Athreya et al. 2015; Gubbi et al. 2020; Puri et al. 2020). When plenty of resources are available in the forest, the big cats, especially tiger, never venture in human habituations (Karanth et al. 2004; Wang and Macdonald 2009; Odden et al. 2010; Bhattarai and Kindlmann 2018). In disturbed habitats, the leopard partially relies on domestic prey, while the tiger depends solely on wild prey (Odden et al. 2010; Athreya et al. 2016). To the question "do the carnivores in tea estates can control the wild herbivore problem?" villagers responded "we know how to control the crop raiders, for that we don't need another risk". Thus, the primary questionnaire survey gives a clear idea regarding the various prey species and the predators present in their locality and the people's perception towards the wild animals.

The co-occurrence analysis and scat-based prey analysis confirm the above assumptions that diverse prey species are present in the forested shola regions and adjoining 
tea plantations. The tea gardens may buffer human habitation and the forested shola regions (Sidhu et al. 2015). The continuous stretch of the tea gardens in the NFD also effectively connects the fragmented shola regions. The co-occurrence of co-predators and prey species without negative interaction shows a diverse and robust prey base in the NFD. The dietary pattern of predators indicates effective resource partitioning of the leopard with the tiger. We observed tiger - leopard coexistence in 44 grid cells, and both co-predators have a significant correlation with the sambar deer. The habitat suited for a tiger is also a habitat suited for the leopard, depending on the same prey resources (Kafley et al. 2019). The tiger exhibited only random associations with small prey like barking deer, while the leopard had positive associations. Large-bodied wild ungulates such as the sambar, wild boar, gaur, and chital are a chief constituent of the tiger diet (Mondal et al. 2011; Hayward et al. 2012; Basak et al. 2020). The proportion of the domestic prey is almost zero in the tiger diet, and the buffalo hairs observed in the scat can be feral or free-ranging. The NFD has a large feral buffalo (Toda buffalo breed) population established from a free-ranging domestic breed. These buffalos are a unique breed maintained by the Toda tribes, a primitive tribal group in the Nilgiri Hills. The nominal proportion of domestic prey in the leopard diet also validates the availability of wild prey and sustainable competition in this region. Puri et al. (2020) reported from the fragmented forested landscape of central India that the free-ranging dogs and the domestic prey together constitute only $3 \%$ of the leopard diet. We hypothesize that when there is competition from the tiger in the shola region, leopards find it easy to prey on wild herbivores in shola fringes and tea estates.

The overlap of humans and wild animal necessities in an area leads to human-wildlife conflict, which peaks in fragmented regions with high human density (Ogada et al. 2003; Shankar et al. 2020). Tiger occupancy negatively correlates to the intensity and the magnitude of human disturbance (Harihar and Pandav 2012; Barber-Meyer et al. 2013; Steinmetz et al. 2013; Kafley et al. 2016). The observed tiger/leopard mortality rate in the NFD indicates that in the past ten years around five tigers and ten leopards were killed or died. The tiger mortality indicates that the NFD also faces threat due to human-induced mortality as reported previously (Sunquist 1981; Smith 1993; Singh et al. 2015a). The studies from Rathambore (Singh et al. 2015a) recorded an annual animal death of 2.4/year, which is quite large in comparison to the NFD. Exploitation (e.g., poaching, killing) and the presence of prey in high density determine the fine-scale existence of the tiger in a human-dominated landscape (Carter et al. 2012). Tiger killing/mortality occurred only in the shola regions, while that of the leopard was in tea gardens.
The frequent reports of leopard conflicts (e.g., human attack, cattle lifting, poisoning in retaliation, poaching, mob killing, and killing for self-defence) are from the tea gardens (Bhattacharjee and Parthasarathy 2013). The snares are generally being placed in the tea estates to trap the wild herbivores by the villagers. This is a common trapping practice since snares are easy to setup and place in the animal's path (Aziz et al. 2017). Although snares are generally used to trap wild herbivores, they can also cause serious injuries or mortality to unintended targets (Gubbi et al. 2021). Reports of killing tigers/leopards by poisoning the left-out carcass exist from many localities (Gopal et al. 2010; Tilson et al. 2010; Kalaivanan et al. 2011; Saif and MacMillan 2016; Aziz et al. 2017). It should be assumed that the NFD is an important tiger habitat with an ample prey base, even though reports of livestock picking are less, the conflicts with big cats are common.

Tiger research in the Nilgiris focused mainly on the surrounding lower elevations like Mudumalai (Ramakrishnan et al. 1999), Silent Valley (Balakrishnan 1984), and Bandipur (Johnsingh 1992). The recent identification of tiger habitat in the sub-Himalayan region increased attention towards high-altitude conservation units, but is more prioritized in the northeast (Sarkar et al. 2018). The entire stretch of the Western Ghats shows a 32\% increase in tiger population in ten years (Jhala et al. 2020). This considerable increase indicates the need to expand tiger conservation areas with an ample prey base and minimum disturbance. The increased population leads to intraspecific competition in established reserves and forces the submissive adults to occupy new territories. The high density of tigers in the neighbouring tiger reserves and prey availability can also account for the increased density of tigers in the NFD. The continuous reserve forest ranges of the Wayanad, Mudumalai, Bandipur and the Nagarhole form a major tiger conservation block and acclaim for $>300$ tigers as per the latest tiger population assessment. The high-altitude NFD is situated between other major tiger conservation units and has a significant tiger population and prey base, making it eligible for its designation as a tiger reserve.

\section{CONCLUSIONS}

In conclusion, the present study suggests that the NFD may be merged with the Mukkurthi National Park to form a new high-altitude tiger reserve. The study finds that the reserve has a good prey base, and the region fulfils all the essential criteria to be considered a tiger reserve. The elevation to a tiger reserve would improve the habitat quality, continuity, prey density, action plans and would reduce human-wildlife conflicts, ensuring the free movement of big cats between the reserves, 
thereby maintaining genetic stability between demes or meta-populations.

\section{ACKNOWLEDGMENTS}

The authors acknowledge the Tamil Nadu Forest Department for the necessary permission(WL5(A)/034236/2015 dt.15.12.2015), support, and collaboration rendered for the study. The authors sincerely acknowledge Dr. Shekhar Kumar Niraj IFS, Mr. K.K.Kausal IFS, Mr. R. Rajamohan, ACF and other forest officers, field staff, student volunteers, and villagers who supported and helped during the field survey. We acknowledge Idea Wild, Colorado, USA for the equipment support to the fourth author.

\section{FUNDING}

This research did not receive any specific grant from funding agencies in the public, commercial, or not-forprofit sectors. The equipment provided by Idea Wild, Colorado, USA to Dr. T. T. Shameer is utilized for the research.

\section{DECLARATION OF INTEREST}

The authors declare that they have no known competing financial interests or personal relationships that could have appeared to influence the work reported in this paper.

\section{AUTHOR CONTRIBUTIONS}

GM, JY, GN, SJB, SN done the field work investigation, data curation, and wrote a preliminary script. JM and $\mathrm{BR}$ done data curation, formal analysis and manuscript editing. TTS done software works and conceptualization, RS gathered resources, permissions, supervision and finalization of the script.

\section{REFERENCES}

Ackerman, B. B., F. G. Lindzey, and T. P. Hemker. 1984. Cougar food habits in southern Utah. The Journal of Wildlife Management 48: 147-155.

Adhikarimayum, A. S., and G. V. Gopi. 2018. First photographic record of tiger presence at higher elevations of the Mishmi Hills in the Eastern Hima- layan Biodiversity Hotspot, Arunachal Pradesh, India. Journal of Threatened Taxa 10: 12833-12836. https://doi.org/10.11609/jott.4381.10.13.12833-12836 Aggarwal, M. 2019. Can the upper Himalayas be the new home for tigers in South Asia? https://india.mongabay. com/2019/09/can-the-upper-himalayas-be-the-newhome-for-tigers-in-south-asia/

Athreya, V., M. Odden, J. D. Linnelland, and K. U. Karanth. 2011. Translocation as a tool for mitigating conflict with leopards in human-dominated landscapes of India. Conservation biology 25: 133-141. https://doi.org/10.1111/j.1523-1739.2010.01599.x

Athreya, V., M. Odden, J. D. Linnell, J. Krishnaswamy, and U. Karanth. 2013. Big cats in our backyards: persistence of large carnivores in a human dominated landscape in India. PloS One 8: e57872. https://doi.org/10.1371/journal.pone.0057872

Athreya, V., A. Srivathsa, M. Puri, K. K. Karanth, N. S. Kumar, and K. U. Karanth. 2015. Spotted in the news: using media reports to examine leopard distribution, depredation, and management practices outside protected areas in Southern India. PLoS One 10: p.e0142647. https://doi.org/10.1371/journal.pone.0142647

Athreya, V., M. Odden, J. D. Linnell, J. Krishnaswamy, and K. U. Karanth. 2016. A cat among the dogs: leopard Panthera pardus diet in a human-dominated landscape in western Maharashtra, India. Oryx 50: 156-162. https://doi.org/10.1017/S0030605314000106

Aziz, M. A., S. Tollington, A. Barlow, J. Goodrich, M. Shamsuddoha, M. A. Islam, and J. J. Groombridge. 2017. Investigating patterns of tiger and prey poaching in the Bangladesh Sundarbans: Implications for improved management. Global Ecology and Conservation 9: 70-81. https://doi.org/10.1016/j.gecco.2016.12.001

Bailey, T. N. 1993. The African leopard: ecology and behavior of a solitary felid. New York: Columbia University Press.

Balakrishnan, M. 1984. The larger mammals and their endangered habitats in the Silent Valley forests of south India. Biological Conservation 29: 277-286. https://doi.org/10.1016/0006-3207(84)90103-4

Barber-Meyer, S., S. Jnawali, J. Karki, P. Khanal, S. Lohani, B. Long, D. MacKenzie, B. Pandav, N. Pradhan, and R. Shrestha. 2013. Influence of prey depletion and human disturbance on tiger occupancy in Nepal. Journal of Zoology 289: 1018. https://doi.org/10.1111/j.14697998.2012.00956.x

Basak, K., M. Ahmed, M. Suraj, B. V. Reddy, O. P. Yadav, and K. Mondal. 2020. Diet ecology of tigers and leopards in Chhattisgarh, central India. Journal of Threatened Taxa 12: 15289-15300. https://doi.org/10.11609/jott.5526.12.3.15289-15300

Bhattacharjee, A., and N. Parthasarathy. 2013. Coexisting with large carnivores: a case study from Western Duars, India. Human Dimensions of Wildlife 18: 20-31. 
https://doi.org/10.1080/10871209.2012.698403

Bhattarai, B. P., and P. Kindlmann. 2018. Human disturbance is the major determinant of the habitat and prey preference of the Bengal tiger (Panthera tigris tigris) in the Chitwan National Park, Nepal. European Journal of Ecology 4: 13-21. https://doi.org/10.2478/eje-2018-0002

Bhattarai, B. R., and K. Fischer. 2014. Human-tiger Panthera tigris conflict and its perception in Bardia National Park, Nepal. Oryx 48: 522-528. https://doi.org/10.1017/S0030605313000483

Carbone, C., and J. L. Gittleman. 2002. A common rule for the scaling of carnivore density. Science 295: 2273 2276. https://doi.org/10.1126/science.1067994

Carter, N. H., B. K. Shrestha, J. B. Karki, N. M. B. Pradhan, and J. Liu. 2012. Coexistence between wildlife and humans at fine spatial scales. Proceedings of the National Academy of Sciences 109: 15360-15365.

Champion, H. G., and S. K. Seth. 1968. A revised survey of the forest types of India. Delhi: Manager of Publications.

Colwell, R. K., and D. J. Futuyma. 1971. On the measurement of niche breadth and overlap. Ecology 52: 567-576. https://doi.org/10.2307/1934144

Crooks, K. R. 2002. Relative sensitivities of mammalian carnivores to habitat fragmentation. Biological Conservation 16: 488-502. https://doi.org/10.1046/j.1523-1739.2002.00386.x

Easa, P. S. 1995. Prey predator studies in Eravikulam National Peechi. (IN): Kerala Forest Research Institute research report. Report No 105 .

Global Tiger Forum. 2019. Status of Tiger Habitats in High Altitude Ecosystems of Bhutan, India and Nepal (Situation Analysis). http://globaltigerforum.org/wp-content/ uploads/2019/09/Final-HAT-VERSION-28-AUGUST20191.pdf (accessed on18 March 2021).

Gompper, M., and A. Vanak. 2008. Subsidized predators, landscapes of fear and disarticulated carnivore communities. Animal Conservation 11: 13-14. https://doi.org/https://doi.org/10.1111/j.1469-1795.2008.00160.x

Gompper, M. E., D. B. Lesmeister, J. C. Ray, J. R. Malcolm, and R. Kays. 2016. Differential habitat use or intraguild interactions: what structures a carnivore community? PloS One 11: e0146055. https://doi.org/10.1371/journal.pone.0146055

Gopal, R., Q. Qureshi, M. Bhardwaj, R. J. Singh, and Y. V. Jhala. 2010. Evaluating the status of the endangered tiger Panthera tigris and its prey in Panna Tiger Reserve, Madhya Pradesh, India. Oryx 44: 383-389. https://doi.org/10.1017/S0030605310000529

Graham, K., A. P. Beckerman, and S. Thirgood. 2005. Human-predator-prey conflicts: ecological correlates, prey losses and patterns of management. Biological Conservation 122: 159-171. https://doi.org/10.1016/j.biocon.2004.06.006
Griffith, D. M., J. A. Veech, and C. J. Marsh. 2016. Cooccur: probabilistic species co-occurrence analysis in R. Journal of Statistical Software 69: 1-17. https://doi.org/10.18637/jss.v069.c02

Gubbi, S., K. Sharma, and V. Kumara. 2020. Every hill has its leopard: patterns of space use by leopards (Panthera pardus) in a mixed use landscape in India. Peer J. 8: p.e10072. https://doi.org/10.7717/peerj.10072

Gubbi, S., A. Kolekarand, and V. Kumara. 2021. Quantifying Wire Snares as a Threat to Leopards in Karnataka, India. Tropical Conservation Science 14: 19400829211023264. https://doi.org/10.1177/19400829211023264

Gurung, B., J. L. D. Smith, C. Mcdougal, J. B. Karki, and A. Barlow. 2008. Factors associated with human-killing tigers in Chitwan National Park, Nepal. Biological Conservation 141: 3069-3078. https://doi.org/10.1016/j.biocon.2004.06.006

Harihar, A., and B. Pandav. 2012. Influence of connectivity, wild prey and disturbance on occupancy of tigers in the human-dominated western Terai Arc Landscape. PloS One 7: e40105. https://doi.org/10.1371/journal.pone.0040105

Harihar, A., A. J. Kurien, B. Pandav, and S. P. Goyal. 2007. Response of tiger population to habitat, wild ungulate prey and human disturbance in Rajaji National Park, Uttarakhand, India. Wildlife Institute of India. Dehradun. https://www.nfwf.org/sites/default/files/ finalreports1/6897_FinaltechnicalReport.pdf

Hayward, M. W., W. Jedrzejewski, and B. Jedrzejewska. 2012. Prey preferences of the tiger Panthera tigris. Journal of Zoology 286: 221-231. https://doi.org/10.1111/j.1469-7998.2011.00871.x

Hill, M. O. 1973. Diversity and evenness: a unifying notation and its consequences. Ecology 54: 427-432. https://doi.org/10.2307/1934352

Hines, J. E., J. D. Nichols, J. A. Royle, D. I. MacKenzie, A. M. Gopalaswamy, N. S. Kumar, and K. U. Karanth. 2010. Tigers on trails: occupancy modelling for cluster sampling. Ecological Applications 20: 1456-1466. https://doi.org/10.1890/09-0321.1

Hurlbert, S. L. 1978. The measurement of niche overlap and some relatives. Ecology 59: 67-77. https://doi.org/10.2307/1936632

Inskip, C., and A. Zimmermann. 2009. Human-felid conflict: a review of patterns and priorities worldwide. Oryx 43: 18-34. https://doi.org/10.101017/S003060530899030X

Jhala, Y. V., R. Gopal, and Q. Qureshi. 2008. Status of tigers, co-predators and prey in India by National Tiger Conservation Authority and Wildlife Institute of India. TR08/001,164. http://www.catsg.org/fileadmin/ filesharing/3.Conservation_Center/3.2._Status_Reports/Tiger/Jhala_et_al_2008_Status_of_tigers_and_ their_prey_in_India.pdf

Jhala, Y. V., Q. Qureshi, and A. K. Nayak. 2020. Status of tigers, copredators and prey in India, 2018. National 
Tiger Conservation Authority, Government of India. New Delhi, and Wildlife Institute of India, Dehradun.

Jhala, Y., R. Gopal, V. Mathur, P. Ghosh, H. S. Negi, S. Narain, S. P. Yadav, A. Malik, R. Garawad, and Q. Qureshi. 2021. Recovery of tigers in India: Critical introspection and potential lessons. People and Nature 3: 281-293. https://doi.org/10.1002/pan3.10177

Johnsingh, A. J. T. 1983. Large mammalian prey-predators in Bandipur. Journal of the Bombay Natural History Society 80: 1-57.

Johnsingh, A. J. T. 1992. Prey selection in three large sympatric carnivores in Bandipur. Mammalia 56: 517-526. https://doi.org/10.1515/mamm.1992.56.4.517

Johnsingh, A. T., R. Raghunath, R. Pillay, and M. D Madhusudan. 2010. Ensuring the future of the tiger and other large mammals in the southern portion of the Nilgiri Biosphere Reserve, Southern India. Journal of the Bombay Natural History Society 107: 77.

Kafley, H., M. E. Gompper, M. Sharma, B. R. Lamichane, and R. Maharjan. 2016. Tigers (Panthera tigris) respond to fine spatial-scale habitat factors: occupancy-based habitat association of tigers in Chitwan National Park, Nepal. Wildlife research 43: 398-410. https://doi.org/10.1071/WR16012

Kafley, H., B. R. Lamichane, R. Maharjan, M. Khadka, N. Bhattarai, and M. E. Gompper. 2019. Tiger and leopard co-occurrence: intraguild interactions in response to human and livestock disturbance. Basic and Applied Ecology 40: 78-89. https://doi.org/10.1016/j.baae.2019.07.007

Kalaivanan, N., R. Venkataramanan, C. Sreekumar, A. Saravanan, and R. K. Srivastava. 2011. Secondary phorate poisoning of large carnivores in India. European Journal of Wildlife Research 57: 191-194.

Karanth, K. U., and M. E. Sunquist. 1995. Prey selection by tiger, leopard and dhole in tropical forests. Journal of Animal Ecology 64: 439-450. https://doi.org/10.2307/5647

Karanth, K. U., and M. E. Sunquist. 2000. Behavioural correlates of predation by tiger (Panthera tigris), leopard (Panthera pardus) and dhole (Cuon alpinus) in Nagarahole, India. Journal of Zoology 250: 255-265. https://doi.org/10.1111/j.1469-7998.2000.tb01076

Karanth, K. U., J. D. Nichols, N. S. Kumar, W. A. Link, and J. E. Hines. 2004. Tigers and their prey: predicting carnivore densities from prey abundance. Proceedings of the National Academy of Sciences 101: 4854-4858. https://doi.org/10.1073/pnas.0306210101

Karanth, K. U., A. M. Gopalaswamy, N. S. Kumar, S. Vaidyanathan, J. D. Nichols, and D. I. MacKenzie. 2011. Monitoring carnivore populations at the landscape scale: occupancy modelling of tigers from sign surveys. Journal of Applied Ecology 48: 1048-1056. https://doi.org/10.1111/j.1365-2664.2011.02002.x

Karanth, K. U., A. Srivathsa, D. Vasudev, M. Puri,
R. Parameshwaran, and N. S. Kumar. 2017. Spatiotemporal interactions facilitate large carnivore sympatry across a resource gradient. Proceedings of the Royal Society B: Biological Sciences 284: 20161860. https://doi.org/10.1098/rspb.2016.1860

Kolipakam, V., S. Singh, B. Pant, Q. Qureshi, and Y. V. Jhala. 2019. Genetic structure of tigers (Panthera tigris tigris) in India and its implications for conservation. Global Ecology and Conservation 20: 1-14. https://doi.org/10.1016/j.gecco.2019.e00710

Koppikar, B. R., and J. H. Sabnis. 1976. Identification of hairs of some Indian mammals. Journal of the Bombay Natural History Society 73: 5-20.

Kshettry, A., S. Vaidyanathan, and V. Athreya. 2017. Leopard in a tea-cup: A study of leopard habitat-use and human-leopard interactions in north-eastern India. PLoSOne 12: e0177013. https://doi.org/10.1371/journal.pone.0177013

Levins, R. 1968. Evolution in changing environments: some theoretical explorations. Princeton University Press.

Linkie, M., D. J. Martyr, J. Holden, A. Yanuar, A. T. Hartana, J. Sugardjito, and N. Leader-Williams. 2003. Habitat destruction and poaching threaten the Sumatran tiger in Kerinci Seblat National Park, Sumatra. Oryx 37: 41-48. https://doi.org/10.1017/S0030605303000103

Mishra, C., M. D. Madhusudan, and A. Datta. 2006. Mammals of the high altitudes of western Arunachal Pradesh, eastern Himalaya: an assessment of threats and conservation needs. Oryx 40: 29-35. https://doi.org/10.107/S0030605306000032

Mondal, K., S. Gupta, Q. Qureshi, and K. Sankar. 2011. Prey selection and food habits of leopard (Panthera pardus fusca) in Sariska Tiger Reserve, Rajasthan, India. Mammalia 75: 201-205. https://doi.org/10.1515/mamm.2011.011

Navya, R., V. Athreya, D. Mudappa, and T. S. Raman. 2014. Assessing leopard occurrence in the plantation landscape of Valparai, Anamalai Hills. Current Science 107: 1381-1385.

Nayak, B. P., P. R. Jena, and S. Chaudhury. 2020. Public Expenditure Effectiveness for Biodiversity Conservation: Understanding the Trends for Project Tiger in India. Journal of Forest Economics 35: 229-265.

Nittu, G., P. M. Bhavana, T. T. Shameer, B. Ramakrishnan, R. Archana, K. K. Kaushal, G. D. Khedkar, G. Mohan, M. Jyothi, and R. Sanil. 2021. Simple Nested Allele-Specific approach with penultimate mismatch for precise species and sex identification of tiger and leopard. Molecular Biology Reports 48: 1667-1676. https://doi.org/10.1007/s11033-021-06139-w

Norton, P. M., S. R. Henley, A. B. Lawson, and G. Avery. 1986. Prey of leopards in four mountainous areas of the south-western Cape Province. South African Journal of Wildlife Research 16: 47-52.

Odden, M., P. Wegge, and T. Fredriksen. 2010. Do tigers 
displace leopards? If so, why? Ecological Research 25: 875-881. https://doi.org/10.1007/s11284-010-0723-1

Odden M., V. Athreya, S. Rattan, and J. D. Linnell. 2014. Adaptable neighbours: movement patterns of GPS-collared leopards in human dominated landscapes in India. PLoSOne 9: e112044. https://doi.org/10.1371/journal.pone.0112044

Ogada, M. O., R. Woodroffe, N. O. Oguge, and L. G. Frank. 2003. Limiting depredation by African carnivores: the role of livestock husbandry. Conservation Biology 17: 1521-1530. https://doi.org/10.1111/j.15231739.2003.00061.x

Pianka, E. R. 1986. Ecology and Natural History of Desert Lizards. Princeton University Press.

Puri, M., A. Srivathsa, K. K. Karanth, I. Patel, and N. S. Kumar. 2020. The balancing act: Maintaining leopard-wild prey equilibrium could offer economic benefits to people in a shared forest landscape of central India. Ecological Indicators 110: 105931. https://doi.org/10.1016/j.ecolind.2019.105931

QGIS Development Team. 2009. QGIS Geographic Information System. Open Source Geospatial Foundation. http://qgis.org.

Rabinowitz, A. 1989. The density and behaviour of large cats in a dry tropical forest mosaic in Huai Kha Khaeng Wildlife Sanctuary, Thailand. Natural History Bulletin of the Siam Society 37: 235-251.

Ramakrishnan, U., R. G. Coss, and N. W. Pelkey. 1999. Tiger decline caused by the reduction of large ungulate prey: evidence from a study of leopard diets in southern India. Biological Conservation 89: 113-120. https://doi.org/10.1016/S0006-3207(98)00159-1

Ramesh, T., R. Kalle, K. Sankar, Q. Qureshi, A. J. Giordanoand, and C. T. Downs. 2019. To resettle or not? Socioeconomic characteristics, livelihoods, and perceptions toward resolving human-tiger conflict in the Nilgiri Biosphere Reserve, India. Land Use Policy 83: 32-46. https://doi.org/10.1016/j.landusepol.2019.01.019

Ripple, W. J., J. A. Estes, R. L. Beschta, C. C. Wilmers, E. G. Ritchie, M. Hebblewhite, J. Berger, B. Elmhagen, M. Letnic, and M. P. Nelson. 2014. Status and ecological effects of the world's largest carnivores. Science 343: 1241484. https://doi.org/10.1126/science.1241484

RStudio Team. 2020. RStudio: Integrated Development for $R$. Boston, MA: R Studio, PBC. URL http://www.rstudio.com/

Sagar, V., C. B. Kaelin, M. Natesh, P. A. Reddy, R. K. Mohapatra, H. Chhattani, P. Thatte, S. Vaidyanathan, S. Biswas, S. Bhatt, S. Paul, Y. V. Jhala, M. M. Verma, B. Pandav, S. Mondol, G. S. Barsh, D. Swain, and U. Ramakrishnan. 2021. High frequency of an otherwise rare phenotype in a small and isolated tiger population. Proceedings of the National Academy of Sciences 118 (39). https://doi.org/10.1073/pnas.2025273118

Saif, S., and D.C. MacMillan. 2016. Poaching, trade, and consumption of tiger parts in the Bangladesh Sundarbans. In The Geography of Environmental Crime, edited by Potter, G. R., Nurse, A., Hall, M., 13-32. London: Palgrave Macmillan. https://doi.org/10.1057/978-1-137-53843-7_2

Sanil, R., T. T. Shameer, and P. S. Easa. 2014. Albinism in jungle cat and jackal along the coastline of the southern Western Ghats. Cat News 61: 23-25.

Sarkar, M. S., H. Segu, J. V. Bhaskar, R. Jakher, S. Mohapatra, K. Shalini, S. Shivaji, and P. A. Reddy. 2018. Ecological preferences of large carnivores in remote, high-altitude protected areas: insights from Buxa Tiger Reserve, India. Oryx 52: 66-77. https://doi.org/10.1017/S0030605317000060

Seidensticker, J. 1976. On the ecological separation between tigers and leopards. Biotropica 8: 225-234. https://doi.org/10.2307/2989714

Selvan, K. M., G. G. Veeraswami, S. Lyngdoh, B. Habib, and S. A. Hussain. 2013. Prey selection and food habits of three sympatric large carnivores in a tropical lowland forest of the Eastern Himalayan Biodiversity Hotspot. Mammalian Biology 78: 296-303. https://doi.org/10.1016/j.mambio.2012.11.009

Shankar, A., N. Salaria, R. Sanil, S. D. Chackaravarthy, and T. T. Shameer. 2020. Spatio-temporal association of fishing cats with the mammalian assemblages in the East Godavari mangrove delta, India. Mammal Study 45: 1-11. https://doi.org/10.3106/ms2020-0015

Sidhu, S., T. S. Raman, and D. Mudappa. 2015. Prey abundance and leopard diet in a plantation and rainforest landscape, Anamalai Hills, Western Ghats. Current Science 109: 323-330.

Singh, R., Q. Qureshi, K. Sankar, P. R. Krausmanand, and S. P. Goyal. 2013. Use of camera traps to determine dispersal of tigers in semi-arid landscape, western India. Journal of arid environments 98: 105-108. https://doi.org/10.1016/j.jaridenv.2013.08.005

Singh, R., P. R. Krausman, S. P. Goyal, and N. P. S. Chauhan. 2015a. Factors contributing losses of tigers in Ranthambhore Tiger Reserve, India. Wildlife Society Bulletin 39: 670-673. https://doi.org/10.1002/wsb.561

Singh, R., P. Nigam, Q. Qureshi, K. Sankar, P. R. Krausman, S. P. Goyal, and K. L. Nicolson. 2015b. Characterizing human - tiger conflict in and around Ranthambhore Tiger Reserve, western India. European Journal of Wildlife Research 61: 255-261. https://doi.org/10.1007/s10344-014-0895-Z

Singh, S. K., J. Aspi, L. Kvist, R. Sharma, P. Pandey, S. Mishra, R. Singh, M. Agrawal, and S. P. Goyal. 2017. Fine-scale population genetic structure of the Bengal tiger (Panthera tigris tigris) in a human-dominated western Terai Arc Landscape, India. PloS One 12: p.e0174371. https://doi.org/10.1371/journal.pone.0174371

Smith, J. L. D. 1993. The role of dispersal in structuring the Chitwan tiger population. Behaviour 124: 165-195. 
Steinmetz, R., N. Seuaturien, and W. Chutipong. 2013. Tigers, leopards, and dholes in a half-empty forest: assessing species interactions in a guild of threatened carnivores. Biological conservation 163: 68-78. https://doi.org/10.1016/j.biocon.2012.12.016

Sunquist, M. E. 1981. The social organization of tigers (Panthera tigris) in Royal Chitawan National park, Nepal. Smithsonian contributions to zoology.

Thapa, K., and M. J. Kelly. 2017. Prey and tigers on the forgotten trail: high prey occupancy and tiger habitat use reveal the importance of the understudied Churia habitat of Nepal. Biological Conservation 26: 593-616. https://doi.org/10.1007/s10531-016-1260-1

Thapa, K., S. Malla, S. A. Subba, G. J. Thapa, B. R. Lamichhane, N. Subedi, M. Dhakal, K. P. Acharya, M. K. Thapa, P. Neupane, and S. Poudel. 2021. On the tiger trails: Leopard occupancy decline and leopard interaction with tigers in the forested habitat across the Terai Arc Landscape of Nepal. Global Ecology and Conservation 25: e01412. https://doi.org/10.1016/j.gecco.2020.e01412

Tilson, R., P. J. Nyhus, and A. Rubianto. 2010. Poaching and poisoning of tigers in Sumatra for the domestic market. In Tigers of the world, edited by Tilson, R., Nyhus, P. J., 101-112. Cambridge: Academic Press.

Treves, A., and K. U. Karanth. 2003. Human-carnivore conflict and perspectives on carnivore management worldwide. Conservation biology 17: 1491-1499. https://doi.org/10.1111/j.1523-1739.2003.00059.x
Veech, J. A. 2013. A probabilistic model for analysing species co-occurrence. Global Ecology and Biogeography 22: 252-260. https://doi.org/10.1111/j.1466-8238.2012.00789.x

Wang, S. W., and D. W. Macdonald. 2006. Livestock predation by carnivores in Jigme Singye Wangchuck National Park, Bhutan. Biological Conservation 129: 558-565. https://doi.org/10.1016/j.biocon.2005.11.024

Wang, S. W., and D. W. Macdonald. 2009. The use of camera traps for estimating tiger and leopard populations in the high altitude mountains of Bhutan. Biological Conservation 142: 606-613. https://doi.org/10.1016/j.biocon.2008.11.023

Wegge, P., M. Odden, C. P. Pokharel, and T. Storaas. 2009. Predator-prey relationships and responses of ungulates and their predators to the establishment of protected areas: a case study of tigers, leopards and their prey in Bardia National Park, Nepal. Biological Conservation 142: 189-202. https://doi.org/10.1016/j.biocon.2008.10.020

Woodroffe, R., and J. R. Ginsberg. 1998. Edge effects and the extinction of populations inside protected areas. Science 280: 2126-2128. https://doi.org/10.1126/science.280.5372.2126

Yumnam, B., Y. V. Jhala, Q. Qureshi, J. E. Maldonado, R. Gopal, S. Saini, and R. C. Fleischer. 2014. Prioritizing tiger conservation through landscape genetics and habitat linkages. PloS One 9: e111207. https://doi.org/10.1371/journal.pone.0111207

\section{LIST OF SUPPLEMENTARY MATERIALS}
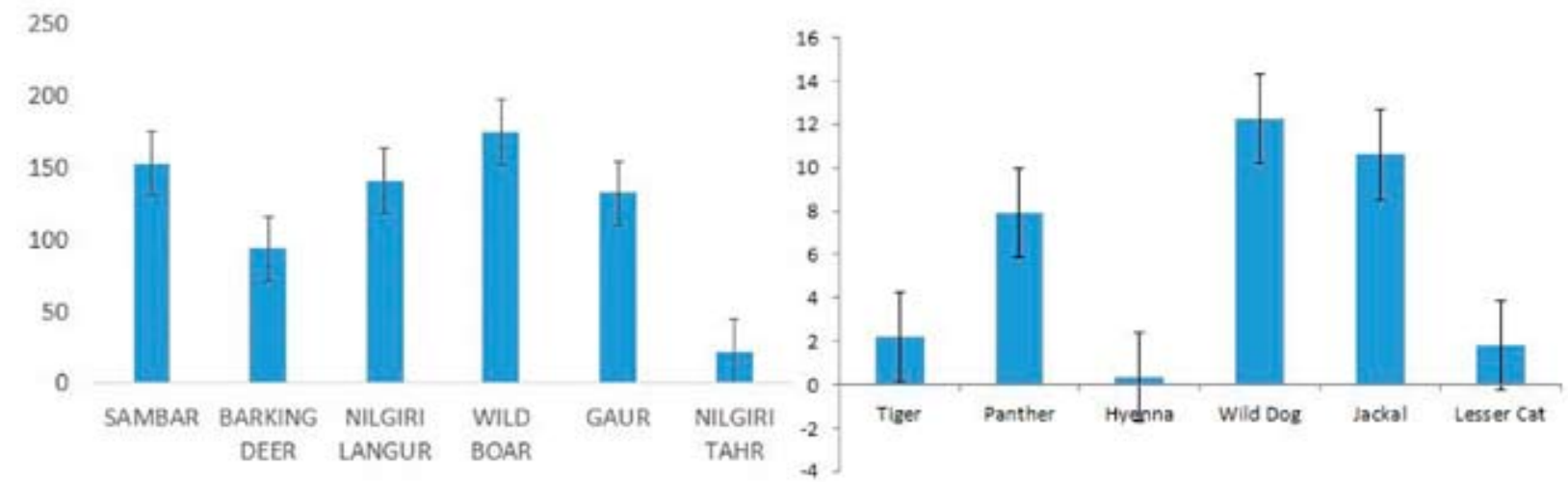

Supplementary Figure S1. Carnivore population assessment in the study area by the Tamil Nadu Forest Department from the years 2005-2016. The value represented here is the mean \pm standard deviation of the random survey done by the forest department with the help of an NGO. This data gives an idea of the prey and predator species present in the reserve. 


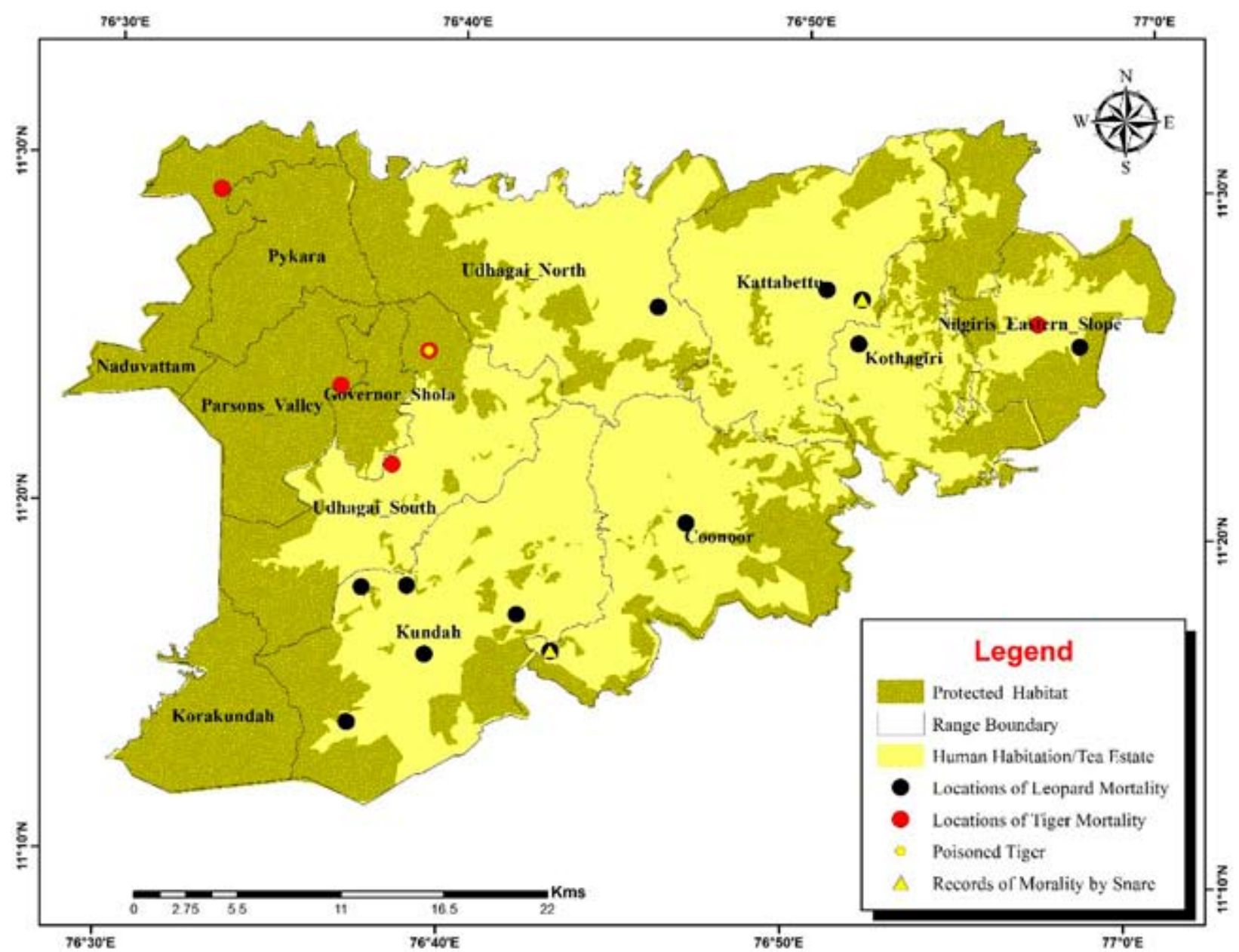

Supplementary Figure S2. The geo-referenced tiger and leopard mortality data for 10 years. The data shows the rate of leopard mortality is $1 /$ year and of tiger is 0.5 year. Tiger mortality mostly happened inside the reserves and leopard mortality in the non-reserve areas. Two records of leopard mortality are due to snare and one mortality of tiger is due to poisoning.

Supplementary Table S3. Co-occurrence analysis indicating species co-occurrence. $P l t<0.05$ and $P g t<0.05$ indicate spatial segregation and positive association.

\begin{tabular}{|l|l|c|c|c|c|c|c|c|}
\hline \multicolumn{1}{|c|}{ Species A } & \multicolumn{1}{|c|}{ Species B } & $\begin{array}{c}\text { Species } \\
\text { A }\end{array}$ & $\begin{array}{c}\text { Species } \\
\text { B }\end{array}$ & $\begin{array}{c}\text { Observed co- } \\
\text { occurrence }\end{array}$ & $\begin{array}{c}\text { Probability of } \\
\text { co-occurrence }\end{array}$ & $\begin{array}{c}\text { Expected co- } \\
\text { occurrence }\end{array}$ & Plt & Pgt \\
\hline Tiger & Leopard & 45 & 56 & 44 & 0.473 & 34.5 & 1 & 0 \\
\hline Tiger & Elephant & 45 & 18 & 15 & 0.152 & 11.1 & 0.99496 & 0.02558 \\
\hline Tiger & Gaur & 45 & 50 & 39 & 0.422 & 30.8 & 1 & 0.00003 \\
\hline Tiger & Sambar & 45 & 53 & 42 & 0.448 & 32.7 & 1 & 0 \\
\hline Tiger & Chital & 45 & 5 & 3 & 0.042 & 3.1 & 0.64091 & 0.71619 \\
\hline Tiger & Wild pig & 45 & 47 & 40 & 0.397 & 29 & 1 & 0 \\
\hline Tiger & Barking deer & 45 & 51 & 42 & 0.431 & 31.4 & 1 & 0 \\
\hline Tiger & Feral buffalo & 45 & 28 & 24 & 0.236 & 17.3 & 0.99991 & 0.00072 \\
\hline Tiger & Common langur & 45 & 3 & 2 & 0.025 & 1.8 & 0.77185 & 0.67384 \\
\hline Tiger & Bonnet macaque & 45 & 40 & 32 & 0.338 & 24.7 & 0.99994 & 0.00042 \\
\hline Tiger & Mouse deer & 45 & 16 & 12 & 0.135 & 9.9 & 0.94071 & 0.17099 \\
\hline Tiger & Nilgiri langur & 45 & 37 & 33 & 0.312 & 22.8 & 1 & 0 \\
\hline Tiger & Nilgiri tahr & 45 & 3 & 3 & 0.025 & 1.8 & 1 & 0.22815 \\
\hline Tiger & Porcupine & 45 & 48 & 39 & 0.405 & 29.6 & 1 & 0 \\
\hline Tiger & Canids & 45 & 30 & 23 & 0.253 & 18.5 & 0.99359 & 0.02389 \\
\hline
\end{tabular}




\begin{tabular}{|c|c|c|c|c|c|c|c|c|}
\hline Species A & Species B & $\begin{array}{c}\text { Species } \\
\text { A }\end{array}$ & $\begin{array}{c}\text { Species } \\
\text { B }\end{array}$ & $\begin{array}{l}\text { Observed co- } \\
\text { occurrence }\end{array}$ & $\begin{array}{l}\text { Probability of } \\
\text { co-occurrence }\end{array}$ & $\begin{array}{l}\text { Expected co- } \\
\text { occurrence }\end{array}$ & $P l t$ & Pgt \\
\hline Tiger & Black napped hare & 45 & 47 & 38 & 0.397 & 29 & 1 & 0.00001 \\
\hline Tiger & Livestock & 45 & 20 & 16 & 0.169 & 12.3 & 0.98992 & 0.04089 \\
\hline Leopard & Elephant & 56 & 18 & 18 & 0.189 & 13.8 & 1 & 0.00386 \\
\hline Leopard & Gaur & 56 & 50 & 47 & 0.525 & 38.4 & 1 & 0 \\
\hline Leopard & Sambar & 56 & 53 & 52 & 0.557 & 40.7 & 1 & 0 \\
\hline Leopard & Chital & 56 & 5 & 5 & 0.053 & 3.8 & 1 & 0.25431 \\
\hline Leopard & Wild pig & 56 & 47 & 46 & 0.494 & 36.1 & 1 & 0 \\
\hline Leopard & Barking deer & 56 & 51 & 51 & 0.536 & 39.1 & 1 & 0 \\
\hline Leopard & Feral buffalo & 56 & 28 & 27 & 0.294 & 21.5 & 0.99994 & 0.00109 \\
\hline Leopard & Common langur & 56 & 3 & 3 & 0.032 & 2.3 & 1 & 0.44569 \\
\hline Leopard & Bonnet macaque & 56 & 40 & 40 & 0.42 & 30.7 & 1 & 0 \\
\hline Leopard & Mouse deer & 56 & 16 & 16 & 0.168 & 12.3 & 1 & 0.0079 \\
\hline Leopard & Nilgiri langur & 56 & 37 & 37 & 0.389 & 28.4 & 1 & 0 \\
\hline Leopard & Nilgiri thar & 56 & 3 & 3 & 0.032 & 2.3 & 1 & 0.44569 \\
\hline Leopard & Porcupine & 56 & 48 & 47 & 0.504 & 36.8 & 1 & 0 \\
\hline Leopard & Canids & 56 & 30 & 30 & 0.315 & 23 & 1 & 0.00002 \\
\hline Leopard & Black napped hare & 56 & 47 & 46 & 0.494 & 36.1 & 1 & 0 \\
\hline Leopard & Livestock & 56 & 20 & 20 & 0.21 & 15.3 & 1 & 0.00183 \\
\hline Elephant & Gaur & 18 & 50 & 17 & 0.169 & 12.3 & 0.99967 & 0.00445 \\
\hline Elephant & Sambar & 18 & 53 & 17 & 0.179 & 13.1 & 0.99882 & 0.01293 \\
\hline Elephant & Chital & 18 & 5 & 3 & 0.017 & 1.2 & 0.98822 & 0.09245 \\
\hline Elephant & Wild pig & 18 & 47 & 16 & 0.159 & 11.6 & 0.99862 & 0.01026 \\
\hline Elephant & Barking deer & 18 & 51 & 17 & 0.172 & 12.6 & 0.99949 & 0.00642 \\
\hline Elephant & Feral buffalo & 18 & 28 & 10 & 0.095 & 6.9 & 0.97682 & 0.07462 \\
\hline Elephant & Common langur & 18 & 3 & 2 & 0.01 & 0.7 & 0.98688 & 0.14842 \\
\hline Elephant & Bonnet macaque & 18 & 40 & 15 & 0.135 & 9.9 & 0.99934 & 0.00465 \\
\hline Elephant & Mouse deer & 18 & 16 & 7 & 0.054 & 3.9 & 0.98776 & 0.05062 \\
\hline Elephant & Nilgiri langur & 18 & 37 & 10 & 0.125 & 9.1 & 0.77226 & 0.41942 \\
\hline Elephant & Nilgiri tahr & 18 & 3 & 2 & 0.01 & 0.7 & 0.98688 & 0.14842 \\
\hline Elephant & Porcupine & 18 & 48 & 16 & 0.162 & 11.8 & 0.99794 & 0.01436 \\
\hline Elephant & Canids & 18 & 30 & 11 & 0.101 & 7.4 & 0.98795 & 0.04406 \\
\hline Elephant & Black napped hare & 18 & 47 & 14 & 0.159 & 11.6 & 0.9542 & 0.13868 \\
\hline Elephant & Livestock & 18 & 20 & 5 & 0.068 & 4.9 & 0.6428 & 0.59441 \\
\hline Gaur & Sambar & 50 & 53 & 48 & 0.497 & 36.3 & 1 & 0 \\
\hline Gaur & Chital & 50 & 5 & 5 & 0.047 & 3.4 & 1 & 0.14106 \\
\hline Gaur & Wild pig & 50 & 47 & 44 & 0.441 & 32.2 & 1 & 0 \\
\hline Gaur & Barking deer & 50 & 51 & 45 & 0.479 & 34.9 & 1 & 0 \\
\hline Gaur & Feral buffalo & 50 & 28 & 25 & 0.263 & 19.2 & 0.99973 & 0.0021 \\
\hline Gaur & Common langur & 50 & 3 & 3 & 0.028 & 2.1 & 1 & 0.31513 \\
\hline Gaur & Bonnet macaque & 50 & 40 & 35 & 0.375 & 27.4 & 0.99999 & 0.00013 \\
\hline Gaur & Mouse deer & 50 & 16 & 15 & 0.15 & 11 & 0.99907 & 0.01075 \\
\hline Gaur & Nilgiri langur & 50 & 37 & 33 & 0.347 & 25.3 & 0.99999 & 0.00011 \\
\hline Gaur & Nilgiri tahr & 50 & 3 & 3 & 0.028 & 2.1 & 1 & 0.31513 \\
\hline Gaur & Porcupine & 50 & 48 & 44 & 0.45 & 32.9 & 1 & 0 \\
\hline Gaur & Canids & 50 & 30 & 28 & 0.281 & 20.5 & 0.99999 & 0.00009 \\
\hline Gaur & Black napped hare & 50 & 47 & 42 & 0.441 & 32.2 & 1 & 0 \\
\hline
\end{tabular}




\begin{tabular}{|c|c|c|c|c|c|c|c|c|}
\hline Species A & Species B & $\begin{array}{c}\text { Species } \\
\text { A }\end{array}$ & $\begin{array}{c}\text { Species } \\
\text { B }\end{array}$ & $\begin{array}{l}\text { Observed co- } \\
\text { occurrence }\end{array}$ & $\begin{array}{l}\text { Probability of } \\
\text { co-occurrence }\end{array}$ & $\begin{array}{l}\text { Expected co- } \\
\text { occurrence }\end{array}$ & Plt & Pgt \\
\hline Gaur & Livestock & 50 & 20 & 16 & 0.188 & 13.7 & 0.94706 & 0.15438 \\
\hline Sambar & Chital & 53 & 5 & 5 & 0.05 & 3.6 & 1 & 0.19105 \\
\hline Sambar & Wild pig & 53 & 47 & 47 & 0.467 & 34.1 & 1 & 0 \\
\hline Sambar & Barking deer & 53 & 51 & 49 & 0.507 & 37 & 1 & 0 \\
\hline Sambar & Feral buffalo & 53 & 28 & 27 & 0.278 & 20.3 & 0.99999 & 0.00017 \\
\hline Sambar & Common langur & 53 & 3 & 3 & 0.03 & 2.2 & 1 & 0.37665 \\
\hline Sambar & Bonnet macaque & 53 & 40 & 38 & 0.398 & 29 & 1 & 0 \\
\hline Sambar & Mouse deer & 53 & 16 & 16 & 0.159 & 11.6 & 1 & 0.00282 \\
\hline Sambar & Nilgiri langur & 53 & 37 & 37 & 0.368 & 26.9 & 1 & 0 \\
\hline Sambar & Nilgiri thar & 53 & 3 & 3 & 0.03 & 2.2 & 1 & 0.37665 \\
\hline Sambar & Porcupine & 53 & 48 & 48 & 0.477 & 34.8 & 1 & 0 \\
\hline Sambar & Canids & 53 & 30 & 30 & 0.298 & 21.8 & 1 & 0 \\
\hline Sambar & Black napped hare & 53 & 47 & 46 & 0.467 & 34.1 & 1 & 0 \\
\hline Sambar & Livestock & 53 & 20 & 20 & 0.199 & 14.5 & 1 & 0.00047 \\
\hline Chital & Wild pig & 5 & 47 & 4 & 0.044 & 3.2 & 0.89788 & 0.41087 \\
\hline Chital & Barking deer & 5 & 51 & 4 & 0.048 & 3.5 & 0.84361 & 0.52242 \\
\hline Chital & Feral buffalo & 5 & 28 & 2 & 0.026 & 1.9 & 0.71619 & 0.64091 \\
\hline Chital & Common langur & 5 & 3 & 0 & 0.003 & 0.2 & 0.80578 & 1 \\
\hline Chital & Bonnet macaque & 5 & 40 & 3 & 0.038 & 2.7 & 0.75541 & 0.5919 \\
\hline Chital & Mouse deer & 5 & 16 & 3 & 0.015 & 1.1 & 0.9928 & 0.0667 \\
\hline Chital & Nilgiri langur & 5 & 37 & 3 & 0.035 & 2.5 & 0.81269 & 0.51321 \\
\hline Chital & Nilgiri tahr & 5 & 3 & 0 & 0.003 & 0.2 & 0.80578 & 1 \\
\hline Chital & Porcupine & 5 & 48 & 4 & 0.045 & 3.3 & 0.886 & 0.43786 \\
\hline Chital & Canids & 5 & 30 & 4 & 0.028 & 2.1 & 0.99051 & 0.08794 \\
\hline Chital & Black napped hare & 5 & 47 & 4 & 0.044 & 3.2 & 0.89788 & 0.41087 \\
\hline Chital & Livestock & 5 & 20 & 3 & 0.019 & 1.4 & 0.98187 & 0.12271 \\
\hline Wild pig & Barking deer & 47 & 51 & 45 & 0.45 & 32.8 & 1 & 0 \\
\hline Wild pig & Feral buffalo & 47 & 28 & 26 & 0.247 & 18 & 1 & 0.00004 \\
\hline Wild pig & Common langur & 47 & 3 & 3 & 0.026 & 1.9 & 1 & 0.26071 \\
\hline Wild pig & Bonnet macaque & 47 & 40 & 34 & 0.353 & 25.8 & 0.99999 & 0.00006 \\
\hline Wild pig & Mouse deer & 47 & 16 & 16 & 0.141 & 10.3 & 1 & 0.00029 \\
\hline Wild pig & Nilgiri langur & 47 & 37 & 35 & 0.326 & 23.8 & 1 & 0 \\
\hline Wild pig & Nilgiri tahr & 47 & 3 & 3 & 0.026 & 1.9 & 1 & 0.26071 \\
\hline Wild pig & Porcupine & 47 & 48 & 44 & 0.423 & 30.9 & 1 & 0 \\
\hline Wild pig & Canids & 47 & 30 & 29 & 0.265 & 19.3 & 1 & 0 \\
\hline Wild pig & Black napped hare & 47 & 47 & 42 & 0.415 & 30.3 & 1 & 0 \\
\hline Wild pig & Livestock & 47 & 20 & 19 & 0.176 & 12.9 & 0.99998 & 0.00044 \\
\hline Barking deer & Feral buffalo & 51 & 28 & 27 & 0.268 & 19.6 & 1 & 0.00004 \\
\hline Barking deer & Common langur & 51 & 3 & 3 & 0.029 & 2.1 & 1 & 0.33483 \\
\hline Barking deer & Bonnet macaque & 51 & 40 & 39 & 0.383 & 27.9 & 1 & 0 \\
\hline Barking deer & Mouse deer & 51 & 16 & 16 & 0.153 & 11.2 & 1 & 0.00136 \\
\hline Barking deer & Nilgiri langur & 51 & 37 & 36 & 0.354 & 25.8 & 1 & 0 \\
\hline Barking deer & Nilgiri tahr & 51 & 3 & 3 & 0.029 & 2.1 & 1 & 0.33483 \\
\hline Barking deer & Porcupine & 51 & 48 & 46 & 0.459 & 33.5 & 1 & 0 \\
\hline Barking deer & Canids & 51 & 30 & 30 & 0.287 & 21 & 1 & 0 \\
\hline Barking deer & Black napped hare & 51 & 47 & 44 & 0.45 & 32.8 & 1 & 0 \\
\hline
\end{tabular}




\begin{tabular}{|c|c|c|c|c|c|c|c|c|}
\hline Species A & Species B & $\begin{array}{c}\text { Species } \\
\text { A }\end{array}$ & $\begin{array}{c}\text { Species } \\
\text { B }\end{array}$ & $\begin{array}{c}\text { Observed co- } \\
\text { occurrence }\end{array}$ & $\begin{array}{l}\text { Probability of } \\
\text { co-occurrence }\end{array}$ & $\begin{array}{c}\text { Expected co- } \\
\text { occurrence }\end{array}$ & Plt & $P g t$ \\
\hline Barking deer & Livestock & 51 & 20 & 20 & 0.191 & 14 & 1 & 0.00018 \\
\hline Feral buffalo & Common langur & 28 & 3 & 2 & 0.016 & 1.2 & 0.94733 & 0.32616 \\
\hline Feral buffalo & Bonnet macaque & 28 & 40 & 22 & 0.21 & 15.3 & 0.99981 & 0.00122 \\
\hline Feral buffalo & Mouse deer & 28 & 16 & 11 & 0.084 & 6.1 & 0.99903 & 0.00595 \\
\hline Feral buffalo & Nilgiri langur & 28 & 37 & 25 & 0.194 & 14.2 & 1 & 0 \\
\hline Feral buffalo & Nilgiri tahr & 28 & 3 & 1 & 0.016 & 1.2 & 0.67384 & 0.77185 \\
\hline Feral buffalo & Porcupine & 28 & 48 & 25 & 0.252 & 18.4 & 0.99993 & 0.00065 \\
\hline Feral buffalo & Canids & 28 & 30 & 18 & 0.158 & 11.5 & 0.99971 & 0.00164 \\
\hline Feral buffalo & Black napped hare & 28 & 47 & 25 & 0.247 & 18 & 0.99996 & 0.00035 \\
\hline Feral buffalo & Livestock & 28 & 20 & 12 & 0.105 & 7.7 & 0.99517 & 0.02009 \\
\hline Common langur & Bonnet macaque & 3 & 40 & 3 & 0.023 & 1.6 & 1 & 0.15885 \\
\hline Common langur & Mouse deer & 3 & 16 & 1 & 0.009 & 0.7 & 0.88102 & 0.52955 \\
\hline Common langur & Nilgiri langur & 3 & 37 & 2 & 0.021 & 1.5 & 0.87507 & 0.51042 \\
\hline Common langur & Nilgiri tahr & 3 & 3 & 0 & 0.002 & 0.1 & 0.88012 & 1 \\
\hline Common langur & Porcupine & 3 & 48 & 2 & 0.027 & 2 & 0.72191 & 0.73149 \\
\hline Common langur & Canids & 3 & 30 & 0 & 0.017 & 1.2 & 0.19842 & 1 \\
\hline Common langur & Black napped hare & 3 & 47 & 1 & 0.026 & 1.9 & 0.2874 & 0.9582 \\
\hline Common langur & Livestock & 3 & 20 & 2 & 0.011 & 0.8 & 0.98167 & 0.18024 \\
\hline Bonnet macaque & Mouse deer & 40 & 16 & 16 & 0.12 & 8.8 & 1 & 0.00001 \\
\hline Bonnet macaque & Nilgiri langur & 40 & 37 & 28 & 0.278 & 20.3 & 0.99996 & 0.00029 \\
\hline Bonnet macaque & Nilgiri tahr & 40 & 3 & 2 & 0.023 & 1.6 & 0.84115 & 0.57271 \\
\hline Bonnet macaque & Porcupine & 40 & 48 & 35 & 0.36 & 26.3 & 1 & 0.00002 \\
\hline Bonnet macaque & Canids & 40 & 30 & 23 & 0.225 & 16.4 & 0.99971 & 0.00165 \\
\hline Bonnet macaque & Black napped hare & 40 & 47 & 33 & 0.353 & 25.8 & 0.99994 & 0.00041 \\
\hline Bonnet macaque & Livestock & 40 & 20 & 15 & 0.15 & 11 & 0.99274 & 0.02947 \\
\hline Mouse deer & Nilgiri langur & 16 & 37 & 11 & 0.111 & 8.1 & 0.97368 & 0.08746 \\
\hline Mouse deer & Nilgiri tahr & 16 & 3 & 0 & 0.009 & 0.7 & 0.47045 & 1 \\
\hline Mouse deer & Porcupine & 16 & 48 & 15 & 0.144 & 10.5 & 0.99957 & 0.00561 \\
\hline Mouse deer & Canids & 16 & 30 & 14 & 0.09 & 6.6 & 1 & 0.00003 \\
\hline Mouse deer & Black napped hare & 16 & 47 & 14 & 0.141 & 10.3 & 0.99601 & 0.02505 \\
\hline Mouse deer & Livestock & 16 & 20 & 9 & 0.06 & 4.4 & 0.9991 & 0.00581 \\
\hline Nilgiri langur & Nilgiri tahr & 37 & 3 & 3 & 0.021 & 1.5 & 1 & 0.12493 \\
\hline Nilgiri langur & Porcupine & 37 & 48 & 35 & 0.333 & 24.3 & 1 & 0 \\
\hline Nilgiri langur & Canids & 37 & 30 & 22 & 0.208 & 15.2 & 0.99979 & 0.00123 \\
\hline Nilgiri langur & Black napped hare & 37 & 47 & 34 & 0.326 & 23.8 & 1 & 0 \\
\hline Nilgiri langur & Livestock & 37 & 20 & 17 & 0.139 & 10.1 & 0.99997 & 0.00029 \\
\hline Nilgiri thar & Porcupine & 3 & 48 & 3 & 0.027 & 2 & 1 & 0.27809 \\
\hline Nilgiri thar & Canids & 3 & 30 & 1 & 0.017 & 1.2 & 0.63398 & 0.80158 \\
\hline Nilgiri thar & Black napped hare & 3 & 47 & 3 & 0.026 & 1.9 & 1 & 0.26071 \\
\hline Nilgiri thar & Livestock & 3 & 20 & 0 & 0.011 & 0.8 & 0.37665 & 1 \\
\hline Porcupine & Canids & 48 & 30 & 30 & 0.27 & 19.7 & 1 & 0 \\
\hline Porcupine & Black napped hare & 48 & 47 & 44 & 0.423 & 30.9 & 1 & 0 \\
\hline Porcupine & Livestock & 48 & 20 & 19 & 0.18 & 13.2 & 0.99996 & 0.00071 \\
\hline Canids & Black napped hare & 30 & 47 & 28 & 0.265 & 19.3 & 1 & 0.00001 \\
\hline Canids & Livestock & 30 & 20 & 14 & 0.113 & 8.2 & 0.99961 & 0.00246 \\
\hline Black Napped Hare & Livestock & 47 & 20 & 17 & 0.176 & 12.9 & 0.9961 & 0.02048 \\
\hline
\end{tabular}

